\title{
Mađarska revolucija 1956. u svjetlu hrvatskoga tiska
}

\author{
DINKO ŠOKČEVIĆ \\ Institut za povijest Istraživačkoga centra za humanističke znanosti \\ Budimpešta, Mađarska \\ sokcsevits@freemail.hu
}

\begin{abstract}
U ovom radu prikazan je odjek mađarske revolucije 1956. u hrvatskom tisku onoga vremena. Rad se uglavnom fokusira na članke i izvješća iz same 1956. godine, djelomično već od ljeta uoči izbijanja revolucije, najviše prostora posvećuje novinskim napisima iz vremena događaja (listopad, studeni, prosinac), a dijelom obuhvaća i napise u tisku iz prvih mjeseci 1957. godine. U radu se prikazuje i analizira odjek mađarskih zbivanja i u vodećim listovima Narodne Republike Hrvatske (Vjesnik, Narodni list), ali isto toliko važnosti pridaje se i člancima u tiskovinama hrvatske emigracije (Hrvatska revija, $\mathrm{Hr}$ vatska država, Hrvatski glas i drugi). Istodobno se rad osvrće i na splet tadašnjih jugoslavensko-mađarskih i jugoslavensko-sovjetskih odnosa.
\end{abstract}

Ključne riječi: destaljinizacija; sovjetski blok; mađarsko-jugoslavenski odnosi; revolucija i narodni ustanak

Revolucija i borba za slobodu mađarskoga naroda 1956. (kako se službeno zovu događaji u listopadu i studenome te godine u mađarskoj historiografiji) jedan je od najvažnijih, ali pomalo (barem u novije vrijeme na Zapadu') i zaboravljenih događaja u povijesti istočnoga dijela podijeljene Europe u doba hladnoga rata. $U$ vrijeme revolucije i jedno vrijeme nakon njezina gušenja u krvi od sovjetske armije Mađarska je dospjela na naslovne stranice vodećih svjetskih medija. Časopis Time u broju od 7. siječnja 1957. stavio je nepoznatoga mađarskog borca za slobodu (Hungarian Freedom Fighter) na svoju naslovnicu kao čovjeka godine 1956. Istaknuti intelektualci, Albert Camus, Hannah Arendt, Jean-Paul Sartre, Milovan Đilas i mnogi drugi, izrazili su svoju soli-

1 Nedavno je njemački televizijski kanal ZDF u svojem dokumentarcu o Nikiti Hruščovu The Red Tsar posvetio mađarskoj revoluciji samo pola rečenice i u njoj praktički opravdao sovjetsku intervenciju riječima da je sovjetski vođa bio „primoran to učiniti da se ne sruši cijeli socijalistički poredak”. Doduše, autori dokumentarca opravdali su i Hruščovljevo sudjelovanje u Staljinovim čistkama kazavši da bi suprotstavljanjem velikom vođi Hruščov stavio na kocku svoj život. Po toj logici, svakoga počinitelja političkoga ili ratnoga zločina koji ima nadređenoga moglo bi se amnestirati. 
darnost s Mađarima i zbivanja mađarske jeseni 1956. ocijenili vrlo važnim trenutkom svjetske povijesti; neki od njih čak su te događaje smatrali početkom pada komunizma. Iako je do konačne propasti komunističke totalitarne diktature u Istočnoj Europi trebalo pričekati još više od tri desetljeća, sovjetska intervencija u Mađarskoj protiv borbe jednoga malog naroda za slobodu (u kojoj su upravo industrijski radnici igrali vodeću ulogu) u velikoj je mjeri oslabila komunističke pokrete na Zapadu i pridonijela slabljenju širenja sovjetskoga utjecaja u svijetu.

Postoji obilje literature i na mađarskom i na mnogim drugim jezicima, publicirani su brojni memoari i zbirke objavljenih dokumenata (arhivske građe mađarske, sovjetske, ali i mnogih drugih država, sudskih dokumenata, medijskih izvješća, tada snimljenih intervjua sa sudionicima događaja, mađarskim emigrantima itd.). Posebno su važni dokumenti iz nekadašnjih tajnih arhiva sovjetskih partijskih i državnih vlasti, koji su pronađeni i objavljeni nakon raspada Sovjetskoga Saveza, ali umnogome pridonose razumijevanju razvoja događaja međunarodnoga konteksta mađarske revolucije 1956., i publicirani američki (i drugi zapadni) državni izvori. Nabrajanje samo najvažnije literature o revoluciji koja je objavljena na mađarskom, engleskom, ruskom i drugim jezicima preraslo bi okvire ovoga članka, kojemu nije cilj prikazivanje i analiza čitavoga tijeka događaja od srpnja do prosinca 1956. - od smjene Mátyása Rákosija, prvoga tajnika Mađarske radničke partije (Magyar Dolgozók Pártja; MDP, u tadašnjim jugoslavenskim tiskovinama navođena kao Partija mađarskih trudbenika, PMT), do raspuštanja i zabrane vodećih organizacija radničkih savjeta, posljednjih čimbenika koji su još branili rezultate revolucije i nakon druge sovjetske intervencije u Mađarskoj - nego prikaz odjeka revolucije u tadašnjim hrvatskim tiskovinama. ${ }^{2}$ Ovdje bih spomenuo samo nekoliko najvažnijih djela o revoluciji 1956. na mađarskom, engleskom i ruskom jeziku. Sveobuhvatna, velika sinteza o 1956. ni na mađarskom još nije objavljena, ali ima nekoliko djela koja daju pregled događaja. Veliki dio publikacija čine objavljeni izvori, memoari. Zapravo je prvo važno djelo izvješće koje donosi pregled događaja i zbir intervjua sa znatnim brojem (112) mađarskih izbjeglica koje je napravio, sakupio i objavio specijalni odbor Ujedinjenih naroda (UN) koji se bavio istraživanjem „mađarskoga pitanja” između siječnja i lipnja 1957. godine. ${ }^{3}$ Prvi pregled,

\footnotetext{
2 Pri ovome prikazu najvažnije literature oslanjao sam se uglavnom (ali ne isključivo) na: VARGA, 1956. A forradalom kronológiája és bibliográfiája, odnosno RAINER, Az 1956os magyar forradalom, gdje autor na kraju daje kratak pregled mađarske i strane literature o temi (str. 175-183). Uglavnom sam nastojao navesti literaturu na engleskom jeziku s obzirom na to da je znatiželjnim hrvatskim čitateljima dostupnija nego radovi na mađarskom jeziku. Neke „manje” sinteze na mađarskom ipak bih spomenuo: RIPP, 1956. Forradalom és szabadságharc Magyarországon; SZAKOLCZAI, Az 1956-os forradalom és szabadságharc; KAHLER, M. KISS, Forradalom és szabadságharc Magyarországon, 1956. O vojnoj povijesti ustanka 1956.: HORVÁTH, 1956 hadikrónikája.

3 United Nations report on the Hungarian uprising 1956.
} 
odnosno zbir dokumenata o međunarodnom medijskom odjeku mađarske revolucije na engleskom jeziku sakupio je Melvin J. Lasky pod naslovom The Hungarian Revolution. A White Book. ${ }^{4}$

Prve knjige o revoluciji na Zapadu su objavili uglavnom mađarski emigranti. Ovdje bih nabrojio tek nekoliko njih, i to samo njihovo englesko odnosno američko izdanje (neke od tih knjiga objavljene su najprije na francuskom ili njemačkom, a najpoznatije, ili najuspješnije, imale su izdanja na svim vodećim svjetskim jezicima), jer čak i broj tih ranih radova prelazi okvire ovoga članka. Prva u nizu je knjiga Behind the Rape of Hungary, koja je najprije izišla na francuskom i tek poslije na engleskom jeziku. Autor je književnik i filozof, mađarski emigrant u Parizu François Fejtő. On je najprije emigrirao pred nacistima, nakon Drugoga svjetskog rata vratio se u Mađarsku, a po uvođenju komunističke diktature ponovo je otišao u Pariz i postao poznat i priznat kao intelektualac u Francuskoj. Predgovor knjizi napisao je glasoviti francuski književnik i filozof Jean-Paul Sartre. ${ }^{5}$

Druga knjiga koju treba spomenuti djelo je Tibora Méraya, također intelektualca emigranta, pod naslovom Thirteen Days That Shook the Kremlin. ${ }^{6}$

Treći rad izišao je nekoliko godina kasnije, ali je zbog uglednoga izdavača brzo postao poznat u krugovima stručnjaka. Autor je bio Ferenc Albert Váli, a naslov knjige Rift and Revolt in Hungary. ${ }^{7}$ Ubrzo je toliko porastao broj knjiga o mađarskoj revoluciji da je profesor Sveučilišta u Torontu (Kanada) Iván L. Halász de Béky sastavio prvu bibliografiju radova o mađarskoj revoluciji. ${ }^{8}$ Od knjiga memoarskoga karaktera bivših sudionika revolucije spomenuo bih samo još djelo Sándora Kopácsija, bivšega zapovjednika budimpeštanske policije iz 1956., koje je bilo vrlo važno jer je prvi put iznio detaljnu priču o suđenju Imreu Nagyu i njegovim drugovima i time definitivno opovrgnuo lažne navode Kádárove Bijele knjige iz 1958. godine. Kopácsi je bio suoptuženik u Nagyevu procesu, osuđen je na doživotnu robiju, 1963. amnestijom je oslobođen, a u vrijeme detanta, u tzv. helsinškom procesu, pušten je u Kanadu, gdje mu je živjela kći. ${ }^{9}$

Idućih desetljeća nastalo je mnogo memoara i znanstvenih knjiga i studija o tom važnom događaju u povijesti hladnoga rata. Pogotovo je prigodom obljetnica revolucije tiskan pozamašan broj radova. Teško je izdvojiti neke od njih; možda vrijedi spomenuti knjigu Billa Lomaxa jer je zanimljiva njegova teza o mađarskoj '56. kao radničkoj revoluciji. ${ }^{10}$ Među sudionicima revolucije važnu ulogu igrali su industrijski radnici, a u redovima ustanika oni su bili

4 LASKY, The Hungarian Revolution.

5 FEJTÖ, Behind the Rape of Hungary.

6 MÉRAY, Thirteen Days That Shook The Kremlin.

VÁLI, Rift and Revolt in Hungary.

8 HALÁSZ de BÉKY, The Bibliography of the Hungarian Revolution 1956; LITVÁN, The Hungarian Revolution of 1956.

9 KOPÁCSI, In the Name of the Working Class.

10 LOMAX, Hungary 1956. 
najbrojniji, čak oko 60 \% boraca činili su mladi radnici. ${ }^{11}$ Nakon pada komunizma i oslobođenja Mađarske od sovjetske okupacije mađarski povjesničari nastojali su objaviti što više radova u inozemstvu na engleskom jeziku, a i dalje su nastajala zanimljiva djela mađarskih autora u emigraciji: od njih bih svakako izdvojio Failed Illusions Charlesa Gatija, knjigu koja na dosta intrigantan način ispituje odgovornost velesila (pogotovo Sjedinjenih Američkih Država / $\mathrm{SAD} /$ ), ali i kritizira mađarsku politiku u vrijeme revolucije. ${ }^{12}$ Poseban doprinos razumijevanju mađarskih događaja u kontekstu američko-sovjetskih odnosa dali su nakon 1989. objavljeni izvori iz tajnih američkih i sovjetskih arhiva. Spomenuo bih knjigu koju je napisao László Borhi, mađarski povjesničar koji je podrobno analizirao položaj Mađarske u svjetlu američkih i sovjetskih izvora u doba hladnoga rata. ${ }^{13}$ Sovjetski arhivi otvorili su se nakon 1991. godine. Prve kopije vrijednih dokumenata iz Moskve Mađarskoj je darovao ruski predsjednik Boris Jeljcin prilikom posjeta Budimpešti, kada se uime Rusije ispričao zbog sovjetske intervencije 1956. godine. Odonda su ruski povjesničari otkrili još mnogo vrijednih izvora koji objašnjavaju situaciju u doba mađarskoga ustanka. ${ }^{14}$ Nastala je i sinteza o sovjetskoj politici prema mađarskom ustanku iz pera Aleksandra Stikalina. ${ }^{15}$

Ovaj rad želi se fokusirati prije svega na hrvatski medijski odjek mađarske revolucije, ali jasno mi je da hrvatskom čitatelju treba prikazati i objasniti pozadinu nekih događaja i razvoj mađarsko-jugoslavenskih odnosa i uoči i za vrijeme i nakon revolucije.

Odjeci mađarskih događanja 1956. u jugoslavenskom tisku (poglavito u beogradskim i novosadskim listovima) i dokumenti o mađarsko-jugoslavenskim vezama relativno su dobro obrađeni u srpskoj i mađarskoj historiografiji i poznati u krugu mađarskoga čitateljstva. ${ }^{16}$

Ovdje bih spomenuo i nekoliko najvažnijih radova iz srpske literature o mađarskoj revoluciji. ${ }^{17}$ Istaknuo bih rad Katarine Kovačević o mađarskim izbjeglicama u Jugoslaviji. Ona upozorava na činjenicu da je u vrijeme mađarskoga ustanka i neposredno poslije Titova vlada nastojala držati granicu zatvorenom. Ponekad je koji pripadnik mađarske službe državne sigurnosti mogao dobiti azil, ali jugoslavenske vlasti i njima su preporučile da je bolje da ostanu kod kuće i bore se za socijalizam. Tek kasnije, kada se počela zatvarati

11 RAINER, Az 1956-os magyar forradalom, 102.

12 GATI, Failed illusions.

13 BORHI, Hungary in the Cold War 1948-1956. Inače, važni američki dokumenti objavljeni su u: Foreign Relations of the United States, 1955-1957. Događaje u kontekstu hladnoga rata analizira i: GRANVILLE, The First Domino.

14 Vrijedne dokumente sadržava: OREHOVA, SEREDA, STIKALIN, Sovjetskij Sojuz i vengerskij krizis 1956. goda.

15 STIKALIN, Prervannaja revoljucija.

16 Top Secret. Magyar-jugoszláv kapcsolatok 1956-1959, sv. I-II. Ova važna izdanja dopunjuje vrijedan rad Đure Frankovića, hrvatskoga istraživača iz Mađarske, koji je nažalost zbog smrti autora ostao u rukopisu. FRANKOVICS, Jugoszláv diplomáciai iratok (I.).

17 KOVAČEVIĆ, „Mađarske izbeglice u Jugoslaviji 1956-1957. godine”, 91-124. 
austrijsko-mađarska granica, pod pritiskom međunarodne javnosti i Jugoslavija je otvorila svoju granicu i od prosinca 1956. do ljeta 1957., kada je na traženje mađarske vlade granica ponovo zatvorena, u zemlju je došlo oko 20 tisuća izbjeglica. Inače, uvjeti u jugoslavenskim prihvatnim logorima, pogotovo onima u kojima su bili smješteni „desničarski elementi” (npr. Gerovo), bili su loši. Kada je jugoslavenska vlada prihvatila pomoć Visokoga povjerenstva UN-a za izbjeglice (UNHCR) i nekih zapadnih zemalja, situacija je postala bolja. Većina mađarskih izbjeglica otišla je u zapadne zemlje, a samo ih je oko 500 ostalo u Jugoslaviji. Zahvaljujući tijesnoj suradnji mađarskih i jugoslavenskih vlasti 2780 izbjeglica vratilo se u Mađarsku.

Također bih istaknuo knjigu Vladimira Popina koja prikazuje odjek mađarske revolucije u beogradskom i vojvođanskom tisku. Knjiga je pisana na srpskom, ali je tiskana u mađarskom prijevodu u Novom Sadu. ${ }^{18}$

Svakako treba spomenuti i knjigu Ivana Ivanjija, svojedobno dopisnika Mladosti, koji je i sam izvještavao iz Budimpešte u vrijeme mađarske revolucije. Iako autor koristi i noviju literaturu o '56-oj, knjiga je u osnovi memoarskoga karaktera, povremeno možda i previše subjektivna. ${ }^{19}$ Autor jedva spominje civilne žrtve koje su ubili pripadnici službe državne sigurnosti ili sovjetske snage (dakle ratne zločine jedne strane), a veliko poglavlje posvećuje linču branitelja budimpeštanskoga partijskoga komiteta na trgu Köztársaság. Istina, tom zločinu 31. listopada je nazočio, a masakre civila koji su spomenute snage počinile na Kossuthovu trgu 25. listopada, a 26. listopada u Mosonmagyaróváru, pa i drugdje, koji su inače prethodili osvetničkim akcijama protiv snaga sigurnosti propaloga režima, Ivanji nije vidio. ${ }^{20}$ Đorđe Zelmanović, novinar zagrebač-

18 POPIN, 1956 - a belgrádi és vajdasági sajtó tükrében.

19 IVANJI, Mađarska revolucija 1956. Godine 2016. knjiga je doživjela novo dopunjeno izdanje.

20 U masakrima je bilo najmanje nekoliko stotina žrtava (službeno je u Mosonmagyaróváru poginulo 50 civila, ali su bolnički listovi nestali u Kádárovo doba; po tvrdnji suvremenika, bilo je oko stotinu žrtava), a u čitavoj Mađarskoj ubijeno je bez suđenja ukupno 37 pripadnika ÁVH-a. U Mosonmagyaróváru dan nakon masakra civila masa je provalila u vojarnu i linčovala dvojicu časnika, a treći se ubio, no glavni zapovjednik István Dudás pobjegao je u Čehoslovačku, a nakon povratka dobio odlikovanje i viši čin od Kádárove vlade. I Hruščov i poslije historiografija u Kádárovo doba govorili su o znatno većem broju ubijenih komunista, ali ti su podaci neutemeljeni. Vidi: RAINER, Az 1956-os magyar forradalom, 105. Osim toga, pod optužbom za linč pred partijskim komitetom na trgu Köztársaság poslije je osuđeno na smrt i pogubljeno 30 osoba (neki među njima uopće nisu bili krivi, nisu sudjelovali u linču, samo su bili u krivo vrijeme na krivom mjestu; Kádárove vlasti pri odmazdi su se naveliko koristile fotografijama zapadnih fotoreportera koje su oni objavili u svojim listovima). Ukupno je prema sudskoj odluci pogubljeno 225 revolucionara (a još više bez sudske odluke po hitnom postupku), a za ratne zločine koje su počinile sovjetske snage i njihovi mađarski saveznici praktički nitko nije odgovarao. Jedino je zapovjednik vojarne u Mosonmagyaróváru István Dudás dospio pred sud 1999., ali je suđenje bilo vrlo dugotrajno. Prvostupanjska odluka donesena je 2001., Dudás je dobio tri godine, ali samo uvjetno, dakle nije morao u zatvor. Nakon toga je uručio žalbu, ali odluku drugostupanjskoga suda nije doživio. Zapovjednik je umro mirno, prije izricanja nove presude, na slobodi, a nakon smrti osumnjičenika proces je zaustavljen. Devedesetih godina slični procesi na mađarskim sudovima završavali su oslobađajućim presudama, ali je na kraju Ustavni sud donio odluku po kojoj je Sovjetski Savez 1956. izveo agresiju protiv Mađarske (naime, nijedna točka Varšavskoga ugovora nije omogućavala intervenciju u zemlji članici iz unutarnjopolitič- 
koga Vjesnika (koji je burnih dana mađarske revolucije izvještavao svoj list iz Budimpešte), u feljtonu za Danas bar je spomenuo masakr na Kossuthovu trgu, ali on je više prostora posvetio hajci na „avoše” (pandan jugoslavenskim udbašima), bivše pripadnike Ureda državne sigurnosti (Államvédelmi Hivatal - ÁVH). Istina je da je bilo prave histerije protiv „avoša”. Moj otac (Matija Šokčević, rođen 1927.) cijelo vrijeme ustanka boravio je u Budimpešti, ali kao povučen, malo i bojažljiv mladić nije sudjelovao u događajima. I on je jednom imao neugodan doživljaj, kada je pristupio na ulici nekoj grupi koja je pažljivo slušala elegantno odjevena čovjeka, možda stranoga diplomata, a neka ga je žena optužila da je (moj otac) sigurno „avoš” i zato prisluškuje. Uspio se izvući tako što je rekao da stanuje u susjednoj ulici i neka dođu s njim i pitaju za njega susjede, pa su ga pustili.

Masakri su imali mnogo više žrtava. Prvih dana (od 24. do 28. listopada) sovjetski tenkovi pucali su na sve što se kretalo. To su činili dijelom i zato što su zapravo došli samo demonstrirati silu, bez pješaštva, i upali u zasjede gradske gerile, pa su bili krajnje nervozni zbog velikih gubitaka. ${ }^{21}$

U hrvatskoj historiografiji ima relativno malo radova o mađarskoj revoluciji. Najvažnija knjiga koja je u Hrvatskoj posvećena temi mađarske revolucije (Mađarska jesen 1956.) nastala je iz pera jednoga od hrvatskih očevidaca događaja, novinara Vjesnika Đorđa Zelmanovića, a objavila ju je nakladnička kuća Fraktura prigodom 50. obljetnice mađarske revolucije 2006. godine. ${ }^{22}$ Možemo se zapitati vrijedi li se posebno baviti napisima o mađarskoj revoluciji objavlje-

kih razloga, a boravak sovjetskih trupa u Mađarskoj Kádárova vlada regulirala je bilateralnim sporazumom tek 1957.), a u skladu s tim u zemlji se vodio rat i takvi masakri su ratni zločini protiv čovječnosti koji ne idu u zastaru. Zato je mogao biti pokrenut proces protiv Dudása, koji je na kraju ipak završen bez pravomoćne presude. Što se tiče nalogodavaca (komunističkih vođa), sudski proces bio je pokrenut jedino protiv Béle Biszkua, ali je i on prekinut zbog smrti optuženika.

${ }_{21}$ Moj je otac čak dva puta bio u neposrednoj životnoj opasnosti. Prvi put, kada je na poziv Nagyeve vlade da se ljudi vrate na posao, otišao je do svojega radnog mjesta u ulici Nagymező u VI. kvartu Budimpešte, ali ondje nije bilo nikoga, a u povratku je čuo pucnjavu kod Zapadnoga kolodvora, pa je išao zaobilaznim putom preko Ferdinandova mosta i bulevara Váci. Tu je uspješno prešao bulevar, a u međuvremenu je stigao sovjetski tenk i otvorio vatru na ljude koji su iza njega pretrčavali cestu. Drugi put htio je otići kupiti kruh, a pred trgovinom su stajali ljudi u redu, mahom žene, što je vidio kada je stigao na ugao ulice u kojoj je bila prodavaonica. I tu se pojavio sovjetski tenk i pucao u ljude koji su stajali u redu. Otac je imao sreću, mogao se povući iza ugla, ali je vidio kako žrtve pokošene rafalom padaju. U prvom slučaju još možemo pomisliti da tenkist na širokom bulevaru nije mogao znati radi li se o civilima ili ustanicima (i oni su bili u civilu), ali ona druga ulica s trgovinom relativno je uska i vojnik je morao vidjeti u koga puca.

22 ZELMANOVIĆ, Mađarska jesen 1956. Knjigu je priredila Xenia Detoni, a urednik je Seid Serdarević. Uvodnu studiju „Trenutak katarze” napisao je Tvrtko Jakovina; intervju je Lidiji Jósvai dao mađarski povjesničar János M. Rainer, a to je zapravo povijesni esej pod naslovom „Revolucija 1956.”; poglavlje „Zelmanović i Mađari” napisao je Pál E. Fehér; poglavlje „Od specijalnog dopisnika Vjesnika” napisala je Xenia Detoni. Knjiga sadržava faksimile Zelmanovićevih originalnih izvješća u Vjesniku 1956., a najduža poglavlja Zelmanovićevi su memoarski feljtoni „Mađarska jesen” i „Posljednji čin mađarske tragedije 1956-1958.” Prvi je izvorno objavio Danas u nastavcima od 14. listopada 1986. do 27. siječnja 1987., a drugi je objavio Start u lipnju 1989. godine. U Osijeku su 2018. tiskani u hrvatskome prijevodu (prev. Ana Lehocki) memoari člana revolucionarnoga Narodnog vijeća u Pečuhu Lászla Debreczenija Lutanja jednog medicinara u zemlji kaznionica. 
nima u medijima hrvatske republičke članice jugoslavenske federacije u vrijeme događaja kada znamo da je tisak unatoč zvučnim parolama socijalističkoga samoupravljanja (barem pedesetih godina sasvim sigurno) u cijeloj Jugoslaviji ipak u suštini bio pod upravom beogradskoga partijskog središta?

Po mome mišljenju, članke i izvještaje o mađarskim događajima u hrvatskom tisku vrijedi ispitati čak i ako uzmemo u obzir samo njegov jugoslavenski dio jer je, primjerice, vodeći zagrebački list Vjesnik zaposlio zasebnoga budimpeštanskog izvjestitelja, nadarenoga novinara sa znanjem mađarskoga jezika rođenog u Temerinu, Đorđa Zelmanovića, no još i više zbog toga što, kada govorimo o hrvatskom tisku, obavezno moramo uzeti u obzir i listove hrvatske emigracije na Zapadu. Emigrantski listovi su mađarskoj revoluciji i borbi za slobodu pristupali temeljito drugačije od tiska jugoslavenskog režima koji iako je slijedio od sovjetskog modela različiti put - u svojim temeljima ipak je bila komunistička diktatura. U okviru ovoga kratkog rada ne kanim podrobno predstaviti sve napise o mađarskoj temi objavljene u cjelokupnom hrvatskom tisku u Jugoslaviji i inozemstvu, nego samo dati mali uvid u tu bogatu izvornu građu i opisati odnos tih dvaju, po ideološkoj osnovi međusobno poprilično udaljenih, medijskih svjetova na hrvatskom jeziku prema mađarskoj revoluciji, a djelomice bih prikazao i političku pozadinu toga odnosa. Što se tiče Narodne Republike Hrvatske, koncentrirao sam se na dva vodeća zagrebačka dnevna lista, Vjesnik i Narodni list, premda sam pregledao i brojeve iz 1956. nekoliko provincijskih tiskovina (također dnevnih listova) - Novi list, Slobodna Dalmacija, Glas Slavonije - no one su uglavnom objavljivale materijale preuzete od jugoslavenske informativne agencije Tanjug te u njima nisam našao osobito zanimljive tekstove. Za razliku od njih, hrvatski emigrantski tisak prije će privući pozornost čitateljstva. ${ }^{23}$ Hrvatska emigracija na Zapadu zbog svoje oskudne materijalne situacije nije objavljivala dnevni list, nego samo različite časopise koji su izlazili redovito ili čak neredovito, što je zasigurno utjecalo na žanrovski karakter članaka o mađarskim događajima koji su se munjevito odvijali, a ta je činjenica - pored različitoga ideološkog pristupa - autorima a priori omogućila drugačiji kut gledanja od izvjestitelja i novinara hrvatskih dnevnih listova. U ovom ću članku dati uvid u napise o mađarskoj temi u časopisima i tjednicima koji u to vrijeme redovito izlaze (najugledniji ili najpoznatiji mediji hrvatske emigracije): iz periodike Hrvatska revija iz Buenos Airesa i tjednika Hrvatska država iz Münchena, članke iz najstarijega tjednika Hrvata u SAD-u Danica i tjednika Hrvatski glas iz kanadskoga Winnipega, koji je bio blizak Hrvatskoj seljačkoj stranci, te listova Republika Hrvatska i Hrvatska, koji su izlazili u Buenos Airesu, i Zajedničara, glasila Hrvatske bratske zajednice. Nastojao sam prikazati glasila različitih hrvatskih emigrantskih skupina s ra-

23 Hrvatski odjek mađarske revolucije 1956. počeo sam istraživati u Zagrebu u Nacionalnoj i sveučilišnoj knjižnici još u prvoj polovini devedesetih godina, kada sam proučavao sliku Mađara u hrvatskim medijima. Već sam tada uz Vjesnik i Narodni list počeo pregledavati i hrvatski emigrantski tisak. O hrvatskom odjeku mađarske '56. do sada sam publicirao članak samo na mađarskom jeziku: SOKCSEVITS, „Az 1956-os magyar forradalom”. 
zličitom političkom orijentacijom - iako je na kraju u svima njima ocjena mađarske revolucije pretežito pozitivna.

Prije predstavljanja članaka i izvještaja jugoslavenskoga hrvatskog tiska o mađarskim događanjima vrijedilo bi ukratko ocrtati onodobni mađarsko-jugoslavenski odnos i početak sovjetsko-jugoslavenskih veza, koje su na njega presudno utjecale, jer je sve to imalo znatnoga učinka na stav hrvatskih novinara prema mađarskoj revoluciji i na narav njihovih tekstova. Nakon Drugoga svjetskog rata Mađarska je od susjednih država uspjela normalizirati odnose najprije s Jugoslavijom. Mađarsko-jugoslavenski odnos, unatoč teškoj baštini svjetskoga rata (novosadski „hladni dani” i potom „krvna osveta u Bačkoj”), u kratkom vremenu razvio se u pozitivnom smjeru, što nije bio toliko plod nastojanja mađarske diplomacije koliko nastojanja regionalne vlasti Jugoslavije; naime, jugoslavenska partijska elita i maršal Tito osobno zemlji su namijenili vodeću ulogu u regiji i taj su cilj pokušali postići, odnosno potaknuti, potpomoći i pripremiti različitim konfederacijskim/federacijskim zamislima i planovima (u Beogradu je spomenuta i zamisao o jugoslavensko-albanskoj federaciji i o jugoslavensko-bugarskoj, čak i jugoslavensko-mađarskoj konfederaciji). Međutim, veze između Beograda i Budimpešte koje su se lijepo razvijale jednim je udarcem okončao sovjetsko-jugoslavenski konflikt koji je izbio 1948., i to ne iz ideoloških razloga u odnosu na onodobno službeno moskovsko stajalište (titoističko je vodstvo do početka pedesetih godina servilno kopiralo model staljinističkoga sovjetskoga državnog uređenja i tek je nakon prekida sa Sovjetskim Savezom razvilo teoriju i praksu samoupravnoga socijalizma). ${ }^{24}$ Upravo su spomenuta jugoslavenska emancipacijska odnosno regionalna nastojanja izazvala žarku sovjetsku reakciju protiv „titoističke klike" jer staljinistička supersila nije željela vidjeti konkurentno središte vlasti u regiji koju je smatrala zonom utjecaja iako su dotičnu zemlju vodili inače duboko odani komunisti. U Mađarskoj su komunisti pod vodstvom Rákosija, koji je upravo tih mjeseci stekao potpunu političku vlast, u sovjetsko-jugoslavenskom konfliktu dakako stali uz Sovjetski Savez, što je automatski dovelo do brzoga narušavanja mađarsko-jugoslavenskoga odnosa i potpunoga ili gotovo potpunoga prekida najprije partijskih, a do 1949. i državnih veza.

Mađarsko državno vodstvo prihvatilo je aktivnu ulogu u protujugoslavenskoj djelatnosti pod sovjetskom upravom. To su Tito i jugoslavenska partijska elita osobito loše primili, smatrajući da se mađarsko državno čelništvo pokazalo nezahvalnim jer je Jugoslavija u prethodnom razdoblju nakon rata poduzela pozitivne korake prema Mađarskoj. Idućih je godina mađarsko-jugoslavenski odnos bio veoma napet. Zabilježen je niz ozbiljnih graničnih incidenata, premda je za njih bila odgovorna čas jedna, čas druga strana. Nakon Staljinove smrti sovjetsko-jugoslavenski odnos počeo se ublažavati, no nije uslijedilo brzo poboljšanje odnosa između Budimpešte i Beograda. Razlog tomu bila je činjenica

24 O stvarnim prilikama u Jugoslaviji vidi: RADELIĆ, Hrvatska u Jugoslaviji 1945. - 1991., poglavlje „Oblikovanje komunističke Hrvatske i Jugoslavije (1945. - 1954.)”, 134-268, i „Samostalan put (1948. - 1966.)”, 269-328. 
da je na čelu Mađarske radničke partije stajalo isto vodstvo na čelu s Rákosijem koje je konstruiralo sudski proces Rajk i općenito bilo odgovorno za to što su odnosi dviju zemalja između 1948. i 1953. bili narušeni čak u većoj mjeri nego što su Sovjeti očekivali (tako je to barem doživio jugoslavenski politički vrh). ${ }^{25}$ Premda je prva Nagyeva vlada nastojala popraviti odnos između Budimpešte i Beograda, što je donijelo pozitivne promjene na međudržavnoj razini, veze dviju komunističkih partija nisu se popravile sve dok je Rákosi bio na čelu Mađarske radničke partije, odnosno sve do srpnja 1956. (štoviše, nakon smjene Nagya i „ljevičarskoga” preokreta Rákosijeva tabora 1955. osjetno je usporilo i poboljšanje odnosa dviju zemalja). Čak i nakon povlačenja Rákosija, kojega Tito nije osobito volio, novi vođa mađarske Partije Ernő Gerő trebao je za uređivanje odnosa Mađarske radničke partije i jugoslavenske „sestrinske partije" pomoćnu intervenciju sovjetskoga partijskog vodstva. Godine 1955./56. normalizirane su sovjetsko-jugoslavenske partijske i državne veze, premda ne na starim temeljima: i Savez komunista Jugoslavije (SKJ) i Jugoslavija ostali su neovisni o Sovjetskoj komunističkoj partiji (SKP), odnosno Moskvi.

Dok je vodstvo mađarske Partije bilo nepovjerljivo prema Jugoslavenima, jugoslavenski primjer (djelomice obrana neovisnosti o Moskvi, a djelomice model samoupravnoga socijalizma) uživao je veliku popularnost među intelektualcima bliskima Nagyu, pa čak i u širim slojevima mađarskoga društva. O tome svjedoči, primjerice, glasoviti Dan jugoslavenske književnosti u travnju 1956. i druge rasprave Kruga, iliti kružoka ili kluba, Petőfi (Petőfi Kör), zato osnivanje radničkih savjeta ni u danima revolucije nije bilo neovisno o utjecaju modela jugoslavenskoga samoupravnog socijalizma. Međutim, jugoslavenski se uzor slijedilo spontano i ne može se dokazati optužba sovjetskoga vodstva (pa i Kádárove vlade) koja je nastala poslije (u vrijeme sovjetsko-jugoslavenske napetosti zbog davanja azila Nagyevoj skupini u jugoslavenskom veleposlanstvu u Budimpešti) i po kojoj su Tito i njegovi drugovi sudjelovali u pripremi mađarskih događaja 1956. godine. Drugo je pitanje to što bi se Tito veselio nastanku Mađarske koja je neovisna, ali pod komunističkim vodstvom. Povrh toga, radnički savjeti koje su mađarski radnici osnovali u doba revolucije doista su bili izraz demokratskoga samoorganiziranja mađarskoga radništva, za razliku od njihovih jugoslavenskih uzora-prethodnika, koje je ipak inicirala (nakon sukoba Tito - Staljin) Komunistička partija odozgo i bili su pod utjecajem jugoslavenskih komunističkih partijskih organa. Kako piše József Juhász: "Jugoslavenska varijanta samoupravljanja, koja je ponajviše postojala samo u ideološkom smislu, nije se pokazala kao snaga obnove nego samo kao zaseban put u slijepu ulicu državnoga socijalizma."26

25 O mađarsko-jugoslavenskim odnosima vidjeti citirano dvosveščano izdanje Top Secret, uključujući i uvodnu studiju u prvom svesku („A magyar-jugoszláv kapcsolatok 1956-ban“, str. 5-22) u kojoj autori (József Kiss, Zoltán Ripp i István Vida) pružaju i pregled odnosa između 1945. i 1956. Vidi i: MURBER, „Az 1956-os magyar események hatása a jugoszláv-magyar kapcsolatok alakulására és a menekültkérdés", 71-82. Još o toj temi: CLISSOLD, Yugoslavia and the Soviet Union 1939-1973; ĐILAS, Tito; JUHÁSZ, Volt egyszer egy Jugoszlávia.

26 JUHÁSZ, „Pasicstól Titóig”, 56. 
Jugoslavenima je bilo poznato da među Mađarima više njih simpatizira jugoslavenski put socijalizma (ili prije njegovu idealiziranu predodžbu koja se razvila među Mađarima). ${ }^{27}$ Ta je činjenica utjecala na početna izvještavanja jugoslavenskoga tiska o mađarskim događajima, ali zapravo i na čitav pristup Titove politike prema razvoju zbivanja u Mađarskoj, i to ne samo do 4. studenog nego sve do zabrane djelovanja radničkih savjeta i uhićenja njihovih vođa u prosincu 1956. godine. Posebno je u tom pogledu zanimljiv govor Edvarda Kardelja, glavnoga ideologa SKJ, u beogradskoj Narodnoj skupštini 7. prosinca 1956. godine. Govor je održan u doba kada u Mađarskoj nakon slamanja oružanoga otpora ustanika i zabrane djelovanja revolucionarnih vijeća radnički savjeti još djeluju i oni su na održanim reizborima tijekom studenoga svugdje birali za čelnike simpatizere revolucije. Kardelj je u govoru jasno poručio novom mađarskom partijskom vrhu (a zapravo i sovjetskoj Partiji) da na mađarske radničke savjete SKJ gleda kao na šansu mađarskoga društva (a i mađarskih komunista) da se konačno raskine sa staljinizmom Rákosija i Gerőa koji je doveo do revolucije i tragičnih događaja. Govor je sutradan u mađarskom prijevodu objavio novosadski list Magyar Szó, a kako se tvrdi u službenoj noti veleposlanstva Mađarske u Beogradu Saveznom sekretarijatu za vanjske poslove Federativne Narodne Republike Jugoslavije, automobilom jugoslavenskoga veleposlanstva u Budimpešti s diplomatskom registracijom jugoslavenski novinari raznijeli su primjerke lista u najveće budimpeštanske tvornice i predali ih predstavnicima radničkih savjeta. ${ }^{28}$

\footnotetext{
${ }^{27}$ Jugoslavenski diplomat u Budimpešti Milan Georgijević već od proljeća 1956. održavao je redovite kontakte s osobama bliskim Nagyu (to su bili Miklós Gimes i Miklós Vásárhelyi), koji su mu donosili i Nagyeve elaborate o planovima učinkovitijih rješenja izgradnje socijalizma u Mađarskoj. Sjećanje M. Vásárhelyija, 30. 5. 1995. u: Top Secret, sv. I, 156. I sam Tito živo se zanimao za djelatnost Kruga Petöfi, čak je u vezi s famoznom jugoslavenskom raspravom Kruga postavio pitanje mađarskom veleposlaniku Sándoru Kurimszkom u Beogradu 21. srpnja 1956. godine. Izvješće sovjetskoga veleposlanika u Budimpešti J. V. Andropova ministru vanjskih poslova D. T. Šepilovu u: Top Secret, sv. I, dok. br. 20, 100-103. Inače, beogradski tisak donio je detaljna izvješća o djelatnosti Kruga Petőfi: Đuka Julius 1. i 3. srpnja 1956. u Politici, Gavro Altman u Borbi 6. i 7. srpnja 1956., a učinio je to i Ivan Ivanji za Mladost.

28 Verbalna nota od 21. 7. 1958. u: Top Secret, sv. II, dok. br. 140, 395-400. Vrlo je zanimljiv jugoslavenski odgovor; nota jugoslavenskoga veleposlanstva u Budimpešti od 8. 10. 1958. u: Top Secret, sv. II, dok. br. 150, 419-426. U jugoslavenskoj noti opravdano se pobijaju neke lažne tvrdnje mađarske strane o vodećoj ulozi jugoslavenske strane pri organizaciji događaja u Mađarskoj, ali se ne negira spomenuta tvrdnja da su jugoslavenski novinari raznosili Kardeljev govor, nego se tvrdi da je list mađarskih sindikata Népakarat objavio taj govor. To je istina: od 9. do 13. prosinca 1956. list je to objavio u nastavcima, bez komentara. Jugoslavenska strana u noti se tako brani „da ne tvrdi se valjda da je to učinjeno mimo znanja i odobrenja mađarskih vlasti?” Međutim, tu jugoslavenska strana nema pravo jer list još nije bio pod kontrolom Kádárova režima. Koji tjedan prije Kádár je čak izjavio, ljut zbog nekog napisa u Népakaratu, da bi uredništvo lista trebalo staviti pod vojnu cenzuru. Tek je prvih mjeseci 1957. list stavljen pod kontrolu, ali mu je samo 1958. vraćeno staro ime Népszava. Jugoslaveni tvrde i da je Kardeljev govor objavljen i u drugim socijalističkim zemljama. Doista, objavio ga je npr. moskovski Komunist (br. 18, 35-51), ali uz protučlanak, uz kritički komentar A. Rumjanceva (isti broj, 11-34). Vidi: SZTIKALIN, „A magyarok hösiessége elismerésre méltó”, 51-64. Još je zanimljivije da je sam Tito u pismu Centralnom komitetu Sovjetske komunističke partije od 1. veljače 1957. kritizirao jugoslavenske novinare što su dijelili Magyar Szó u tvornicama u Budimpešti, a da nisu tražili dozvolu
} 
Jugoslavenski, pa tako i hrvatski (u Narodnoj Republici Hrvatskoj) tisak od početka listopada pokazivao je živo zanimanje za Mađarsku. To je samo djelomično bio rezultat mađarsko-jugoslavenskih međupartijskih dogovora iza kulisa, koji su se odvijali uz sovjetsko posredovanje da se postigne pomirba dviju partija. Mađarska unutarnja politika doživjela je preokret koji je pobudio zanimanje jugoslavenskih novinara, odnosno tamošnjega javnoga mišljenja. (Doduše, jugoslavenski je tisak već nakon Rákosijeva pada pratio mađarske događaje s većim zanimanjem. Novinar zagrebačkoga Vjesnika Đorđe Zelmanović još je krajem kolovoza napisao intervju s glavnim tajnikom Mađarske radničke partije Ernőom Gerőom, koji je u kraćoj verziji objavio u rujnu i Szabad Nép.) Rehabilitacija Lászla Rajka, koji je bio optužen za titoističke veze i u namještenom sudskom procesu osuđen te pogubljen, kao i rehabilitacija njegovih drugova i njihov ponovni pogreb, živo je zanimala jugoslavensku javnost, što je razumljivo sjetimo li se uloge procesa Rajk u odnosu između Jugoslavije i sovjetskoga tabora. Zagrebački je tisak u prvim danima listopada 1956. iznova posvetio veliku pozornost rehabilitaciji Rajka i njegovih drugova jer je odigrala važnu ulogu u normalizaciji veza Mađarske i Jugoslavije (kao što je 1949. proces pridonio znatnom narušavanju odnosa). I Narodni list i Vjesnik podrobno su izvijestili o događajima. Zelmanović je pak u Budimpešti napisao opsežan intervju s Rajkovom udovicom, što govori o tome koliku su važnost tom slučaju pridavali s jugoslavenske strane. Zagrebački je list intervju naslovio „Okrnjena budimpeštanska justicija”. Vjesnik u istom broju izvještava da će se idućega dana (6. listopada) održati svečani ponovni pogreb Rajka i njegovih drugova. Istu vijest (informaciju o njihovoj rehabilitaciji) objavljuje i Narodni list. No počevši od toga što je mađarsko vodstvo 6. listopada i službeno najavilo da će mađarska Partija i državno izaslanstvo na čelu s Gerőom u nadolazećim danima poći i u službeni posjet Jugoslaviji, materijali mađarske tematike vidno su se umnožili u zagrebačkom tisku. Vijest o posjetu dogovorenom za 15. dan toga mjeseca Vjesnik je objavio još u drugom izdanju toga dana, a Narodni list idućega dana, u nedjeljnom broju od 7. listopada. Gotovo su se svakodnevno objavljivale vijesti o političkoj i gospodarskoj suradnji, o kulturi Mađarske te obnovljenim mađarsko-jugoslavenskim odnosima. Narodni list izvijestio je 9. listopada da zagrebački folklorni ansambl Lado gostuje u Budimpešti, 10. listopada objavio je da se Gerő vratio u Budimpeštu iz Moskve, istoga dana pisao je da je na sjednici mađarskoga partizanskog saveza osuđen kult ličnosti, 12. listopada objavio je informaciju da su u Budimpešti uhićeni pripadnici državne sigurnosne službe Mađarske koji su bili umiješani u nezakonite radnje, 14. listopada prenosi izjavu dužnosnika jugoslavenskoga Ministarstva vanjskih poslova Branka Draškovića u kojoj glede Rajkove rehabilitacije i ponovnoga pokopa hvali odlučnost Mađarske radničke partije da rasvijetli prošlost i s pot-

mađarskih vlasti, ali je odbio optužbu da se Jugoslavija miješala u unutarnje poslove Mađarske. Također je zanimljivo da i Tito spominje da je moskovski Komunist objavio Kardeljev govor i postavlja pitanje: bi li mađarske vlasti onda zabranile i raspačavanje moskovskoga Komunista? Tito je samo zaboravio dodati da je sovjetski list u istom broju donio i članak u kojemu namjerava pobiti Kardeljeve teze. Top Secret, sv. II, dok. 31, 122-138. 
pisom D. B. objavljuje opsežan članak pod naslovom „Odlučnijim korakom”, koji analizira mađarsku situaciju prije Gerőova posjeta, odnosno mađarskojugoslavenski odnos nakon rehabilitacije Rajka i drugova, pogubljenih kao „titoistički špijuni”. Prema komentatoru Narodnoga lista, mađarske su narodne mase imale važnu ulogu u nedavnom unutarnjopolitičkom preokretu: „Pritisak javnosti da se pođe odlučnijim korakom novim putem demokratizacije, učvršćenja zakonitosti i neophodnih reformi u privredi, da se iz 'historije NR Mađarske izbriše sramna uspomena na epohu koja je postojala od 1949. do 1953. godine', bio je veoma snažan.”

Vjesnik je tih dana također često objavljivao materijale mađarske tematike, pa je npr. 6. listopada objavio vijest o raspravi mađarskih i jugoslavenskih hidrografa, 8. listopada podrobno izvijestio o ponovnom pokopu Rajka i njegovih drugova (i citirao dijelove govora), 15. listopada objavio da je Imre Nagy ponovno primljen u Mađarsku radničku partiju, a i urednički članak o mađarskoj situaciji „Ide na bolje” pojavio se u broju od 15. listopada, dakle za dolaska Gerőovih. Dakako, o pregovorima mađarske delegacije u Beogradu oba su zagrebačka dnevna lista izvijestila na prvim stranicama 16. i 17. listopada. Narodni list je 16. listopada i na drugoj stranici objavio materijal mađarske tematike: citirao je list Népszava, po kojemu Rákosi nije bio primoran otići s položaja zbog zdravstvenih razloga nego zbog svojih zločina protiv socijalizma. Na istoj je stranici urednik zagrebačkoga dnevnog lista izabrao citate iz lista Szabad Nép koji ističu važnost jugoslavenskoga posjeta mađarskoga izaslanstva. Vjesnik 16. listopada, uz izvještaj o beogradskom programu mađarske delegacije, također na prvoj stranici piše pozivajući se na Népszavu: „Rákosi saučesnik u Farkasovim zločinima.” Narodni list izvijestio je 17., pa i 18. listopada na prvoj stranici o jugoslavenskim pregovorima mađarske delegacije, a potom je 20. listopada zagrebački posjet Gerőovih od prethodnoga dana (19. listopada) također dospio na naslovnicu. Narodni list u broju od 21. listopada u komentaru o budimpeštanskoj situaciji ističe da „mađarska javnost sa simpatijama prati 'dosljednu borbu rukovodilaca poljskih komunista i poljskog naroda za što korjenitiju likvidaciju političkih, privrednih i moralnih ostataka sektaštva i staljinizma...' ('... i da radosno pozdravlja odluke plenuma CK PURP o povratku Gomulke i drugih u CK').”

Jugoslavensko vodstvo, ali i jugoslavenski, pa tako i hrvatski tisak osjetno su „navijali” za to da destaljinizacija započeta u socijalističkim državama uspije (to su, naime, držali važnim u pogledu vanjskopolitičke situacije Titove Jugoslavije). Zbog toga je SKJ pozorno pratio promjene u poljskoj i mađarskoj unutarnjoj politici i zbog toga je nakon 23. listopada i jugoslavenski (pa i zagrebački) tisak pozitivno ocijenio, barem isprva, mađarski preokret. Prva podrobnija izvješća o događajima od 23. (tj. 24.) listopada u zagrebačkom su se tisku pojavila tek 25. listopada - doduše kao glavna vijest, na prvoj stranici - i temeljila su se na vijestima Mađarskoga radija, odnosno službenim obavijestima mađarske vlade (i stoga govore o „oružanom napadu kontrarevolucionarnih bandi”, „banditi su upali u poduzeća, javne zgrade, a mnoge građane 
i pripadnike oružanih snaga i državne sigurnosti ubili”). Vjesnik 25. listopada prenosi vijest o osnutku novoga Centralnoga komiteta Mađarske radničke partije, donosi popis njegovih novih članova, podrobno informira o imenovanju Nagya predsjednikom vlade te nadugačko citira i Nagyev radijski govor od 24. listopada. Međutim, malo je vjerojatno da je slučajnost to što Vjesnik $\mathrm{u}$ istom broju objektivno izvještava o prosvjedima od 23. listopada i prenosi važne dijelove govora Pétera Veresa, odnosno zahtjeve Saveza književnika koje je javno pročitao.

Vjesnik prvi komentar objavljuje 27. listopada pod naslovom „Obaranje spomenika”. U njemu autor koji se služi inicijalima R. L. smatra demokratske zahtjeve prosvjeda od 23. listopada, odnosno izjednačavanje odnosa sa Sovjetskim Savezom, osjetno pozitivnima, no misli da su se u masu uvečer umiješali „neodgovorni elementi” i „svjesni provokatori” i da su oni izazvali oružane sukobe „u svrhu rušenja narodno-demokratske vlasti”. Istodobno događaje naziva tragičnima i smatra da su se u borbe protiv vlade umiješali i „pošteni i dobronamjerni radnici i mladi”. Komentator oprezno iskazuje povjerenje Nagyu i novom vođi Mađarske radničke partije Jánosu Kádáru te se nada da će stabilizirati situaciju (ispod komentara na istoj stranici navedena je vijest koja se poziva na prijenos budimpeštanskoga radija od 26. listopada, kojoj je urednik hrvatskoga lista dao naslov „Mađarska situacija na putu prema potpunom miru”). Autor na početku članka piše da je „puklo uže” pri prvom pokušaju rušenja Staljinova kipa. Tu činjenicu na kraju članka zagrebački novinar upotrebljava u simboličnom smislu: „Prema svemu sudeći, granitni [sic! - kip je bio brončani] Staljinov spomenik ipak je pao. Uže nije moralo puknuti, ali i unatoč tome, statua se nije mogla održati na nogama."

Ovdje treba spomenuti da su prvi dopisnici jugoslavenskih listova doputovali u Budimpeštu tek 28. listopada (dopisnik Politike Đuka Julius, Borbe Vlada Teslić, Mladosti Ivan Ivanji, Magyar Szóa Mátyás Apró, a odvojeno je stigao dopisnik Vjesnika Đorđe Zelmanović). Međutim, u Budimpešti se našao književnik Dobrica Ćosić, koji je još prije izbijanja revolucije doputovao u Mađarsku kao gost Instituta za kulturne veze (Kulturális Kapcsolatok Intézete). Ćosić je bio svjedokom prvih demonstracija i rušenja Staljinova spomenika i u početku je simpatizirao s prosvjednicima i odobravao njihov revolt protiv staljinizma, ali već je tada bio kritičan prema jakim proturuskim tendencijama u njihovim redovima, a zaključio je i da je tih dana bilo teško biti komunistom u Mađarskoj. Ćosić se nakon sedam dana vratio u Jugoslaviju i još tijekom studenoga svoje doživljaje iz Budimpešte objavio u nastavcima u Borbi, a sljedeće godine u obliku knjige. ${ }^{29}$

Narodni list tek 28. listopada prvi put objavljuje komentar o budimpeštanskoj revoluciji. Pod naslovom „Situacija u Mađarskoj. U povodu tragičnih događaja u Budimpešti” autor na početku članka odmah izražava nadu da će „tragični preokret” ubrzo završiti - zahvaljujući novim vođama mađarske Partije i vlade. I ovaj je zagrebački dnevni list prosvjed održan 23. listopada

29 ĆOSIĆ, Sedam dana u Budimpešti. 
poslijepodne nazvao mirnim i konstruktivnim te za tragični preokret pozvao na odgovornost Gerőa i premijera Andrása Hegedüsa (koji je 1953. zamijenio Nagya na čelu vlade) zato što nisu prije dali ostavku na funkciju. Autor na kraju iskazuje povjerenje Nagyu i Kádáru i nada se da će njihova politika ispuniti očekivanja mađarskih narodnih masa, da će biti sposobni stabilizirati situaciju: „Najavljene mjere nedvojbeno će pridonijeti i stabiliziranju prilika i postati snažnom bazom izgradnje socijalizma u Mađarskoj i ubrzavanja društvenog procesa u pozitivnom pravcu."

Počevši od 29. listopada, od dva zagrebačka dnevna lista zanimljiviji će nam biti Vjesnik; otada je taj list imao vlastitoga izvjestitelja u Mađarskoj, Đorđa Zelmanovića. Zelmanovićev prvi izvještaj „Na poprištu događaja” tih je dana objavljen pod čestim nadnaslovom „Situacija u Mađarskoj”. Zelmanović je izvještaj datirao 28. listopada iz Segedina (mađ. Szeged) i javio da još nije uspio ući u Budimpeštu premda je već pokušao. Pozivajući se na jednoga budimpeštanskog svjedoka, opisuje oružani incident (nepoznate naoružane osobe iz nekog su tramvaja pucale na masu), no o borbama misli da su izbile spontano, da nisu organizirane iz jednoga središta i da nema poveznice među različitim ustaničkim skupinama. Prema Zelmanoviću, oružane akcije „su izgleda u prvom redu odraz revolta, koji se godinama kupio u Madžarskoj i eksplodirao posljednjih dana". Podrobnije izvještava o situaciji u Segedinu, koja je po njemu relativno mirna, pozitivno piše o radničkim vijećima koja se osnivaju diljem zemlje i njihovim zahtjevima, a konkretno o susretu predstavnika radničkih vijeća u Segedinu i lokalnoga vodstva. Izvjestitelj pozdravlja i zahtjev za demokratske promjene, smjenu starih staljinističkih vođa i, štoviše, za povlačenje sovjetskih postrojbi, no smatra čudnom (i ne podržava) izjavu izaslanika radničkoga vijeća poduzeća distribucije električne energije u Segedinu prema kojoj oni neće dati električnu energiju dok se postrojbe ne povuku iz grada. Zelmanović izvještaj zaključuje riječima da je i u Segedinu i u drugim mjestima koja je posjetio opći ugođaj optimističan, a građani s kojima je razgovarao uvjereni su u to da će tragični događaji i poteškoće uskoro završiti.

I Narodni list i Vjesnik objavili su 31. listopada Titovo pismo vodstvu Mađarske radničke partije od 30. listopada, u kojem je ogorčenost mađarskih radnika koja je dovela do tragičnih događaja nazvao djelomično legitimnom i Rákosijeve smatra odgovornima za nastalu situaciju, no istodobno izražava i svoju zabrinutost zbog toga što bi „nastavak sestrinske borbe” imao teške posljedice ne samo za Mađarsku nego i za cijeli međunarodni radnički pokret, te da bi daljnje prolijevanje krvi tjeralo vodu na mlin proturevolucionara. $\mathrm{Na}$ rodni list na prvoj stranici objavljuje samo Titovo pismo, a izvještaji o mađarskim događajima povučeni su na drugu stranicu zbog vijesti o ratu na Bliskom istoku. Narodni list na drugoj stranici broja od 31. listopada navodi odgovor Szabad Népa na tekst moskovske Pravde, u kojem mađarski list odbacuje to što je sovjetski list budimpeštanske događaje nazvao „protunarodnom pustolovinom”. Na istom mjestu Narodni list objavljuje da su ustanici počeli spuštati oružje, situacija se polako normalizira. Zagrebački list objavljuje i to da na poziv budimpeštanske vlade sovjetske postrojbe počinju napuštati mađarski glavni grad, no radnici zahtijevaju potpuno povlačenje sovjetskih postrojbi iz 
zemlje. „Zabrinutost” za mađarski socijalistički režim (odnosno veze Beograda i Moskve) spomenuta u Titovu pismu imala je ulogu u tome što je predstavnik Jugoslavije u glasanju bio suzdržan kada je Vijeće sigurnosti UN-a 29. listopada željelo uvesti mađarsko pitanje na dnevni red - dakako, zagrebački list u broju od 30. listopada objavljuje samo činjenicu suzdržanosti. ${ }^{30}$

Vjesnik 30. listopada objavljuje Nagyevu izjavu od 29. listopada i, pozivajući se na budimpeštanski tisak, piše da je „Gerő dolio ulje na vatru” svojim mjerama prvoga dana (pogotovo time što je odmah pozvao Sovjete u pomoć). Vjesnik i u broju od 31. listopada objavljuje Titovo pismo mađarskoj Partiji. Budimpeštanske vijesti pojavljuju se na trećoj stranici prvoga izdanja lista i na prvoj stranici trećega izdanja pod naslovom „Situacija u Madžarskoj postepeno se smiruje".

Zelmanovićev sljedeći izvještaj - ovoga puta od 31. listopada iz Budimpešte - objavljen je u Vjesniku 1. studenog (novinarev budimpeštanski izvještaj o prethodna dva dana nije dospio do adresata). Naslov članka je „Političko previranje”. U njemu Zelmanović, sada na temelju riječi neimenovanoga sugovornika, piše da se zbog djelovanja klike Rákosi-Gerő vjerna masa kobno pokolebala ne samo u dotadašnju vladu nego i u sam socijalizam, pa vlada sad može nastojati samo stvoriti mir. Zelmanović piše da je Imre Nagy dao izjavu o uvođenju višestranačkoga sustava i pozvao sovjetske postrojbe da se udalje, no one su tek 30 . listopada oko 16 sati počele udovoljavati zahtjevima mađarske vlade. Prema Zelmanoviću, 31. listopada bilo je relativno mirno u gradu. Izvjestitelj je posjetio uredništvo lista Igazság, gdje su ga uvjerili u to da neće biti povratka na fašizam, neće dati tvornice u privatne ruke i neće dopustiti ponovno rađanje veleposjeda. Navodeći konkretne primjere, Zelmanović piše kolike je ozbiljne štete grad pretrpio u dotadašnjim borbama, da javni prijevoz još ne funkcionira te napominje da nema nijednoga čitavog izloga, no dodaje „kako se ovdje s ponosom ističe - nije bilo masovne pljačke”. Izvjestitelj zagrebačkoga lista na kraju članka piše da se situacija normalizira, da se polako uspostavlja opskrba namirnicama, vodom i električnom energijom. „Budimpešta je zaista preživjela teške, ali historijske dane. Sad se uspostavlja red."

Zelmanović je izvještaju od 31. listopada kasno uvečer (23:45) dao naslov „Situacija još nije smirena”. Navodi kratki Nagyev govor pred javnošću, u kojem je objavio da nije on pozvao sovjetske postrojbe (Zelmanović je u prethodnom izvještaju napisao da je Nagyeva popularnost prije opala jer su mu pripisali uvođenje izvanrednoga stanja i pozivanje sovjetskih postrojbi u zemlju) i izjavio da će Mađarska istupiti iz Varšavskoga ugovora. Zelmanović u

30 Predstavnik Jugoslavije u UN-u Jože Brilej 10. siječnja 1957. nije podržao formiranje odbora za istraživanje događaja u Mađarskoj, a 13. rujna 1957. nije prihvatio ni izvješće toga odbora; Top Secret, sv. II, dok. br. 77, 215. Predstavnici Jugoslavije u UN-u tako će postupiti i 1957. i 1958., čime je jugoslavenska diplomacija činila gestu Kádárovu režimu i Sovjetskom Savezu u trenucima tada inače napetih jugoslavensko-mađarskih i jugoslavensko-sovjetskih odnosa. Na temelju dokumenata, Kádár je tu gestu cijenio. Istodobno su mađarski komunisti zamjerili da su se jugoslavenski diplomati - iako su glasali u korist Kádárove vlade - kritički izrazili o događajima i stanju u Mađarskoj u svojim govorima u Općoj skupštini Ujedinjenih naroda. 
tom izvještaju piše o ponovnom osnivanju Seljačke stranke, o susretu Nagya i jugoslavenskoga veleposlanika Soldatića te o imenovanju Pála Malétera zamjenikom ministra obrane. Zelmanović je svoj sljedeći detaljni izvještaj predao 1. studenog pod naslovom „I dalje traje neizvjesnost” jer opći štrajk koji zahtijeva povlačenje sovjetskih postrojbi i dalje traje, premda je izvjestitelj napomenuo da je to bio dotad najmirniji dan u gradu. Opovrgava lažne vijesti o smrti Ferenca Puskása, Nándora Hidegkutija (najpoznatiji mađarski nogometaši, članovi „Zlatne ekipe”, reprezentacije koja je na Svjetskom prvenstvu 1954. bila doduše drugoplasirana, ali prethodno četiri godine nitko u svijetu nije ju mogao pobijediti) i Lászla Pappa (mađarski boksač, trostruki olimpijski prvak). Piše da, prema prvim službenim procjenama, broj poginulih dostiže broj od 10 tisuća (što se poslije pokazalo netočnim). ${ }^{31}$ Zelmanović je još istoga dana u 22:30 poslao novi izvještaj, koji je dobio naslov „Nove sovjetske jedinice ulaze u Madžarsku" i koji zaključuje riječima da grad nervozno čeka razvoj događaja uz svjetlost svijeća u budimpeštanskim prozorima, zapaljenih u povodu Dana mrtvih.

Zelmanović 2. studenog piše sljedeći izvještaj, pod naslovom „Generalni štrajk traje”. U njemu izvještava iz parlamenta, o tamošnjem napetom, nervoznom ozračju zbog toga što sovjetski poslanik Andropov još uvijek nije odgovorio mađarskoj vladi na pitanje o ulasku novih sovjetskih vojnih jedinica. Podrobno izvještava o osnutku Mađarske socijalističke radničke partije (Magyar Szocialista Munkáspárt; MSZMP), ${ }^{32}$ no na temelju razgovora s poznanikom, koji je stari mađarski provincijski dužnosnik, predočava zbunjenost i nesigurnost članova državne Partije. Zelmanović piše o dolasku katoličkih političkih snaga na scenu i o zabrinutom, nesigurnom ozračju budimpeštanskih ulica, no i da Savez književnika skuplja donacije za obitelji osoba poginulih u borbi u kutijama izloženim na ulici, u koje prolaznici bacaju znatne iznose, a nikom ne pada na um otuđiti novac koji je bez nadzora. Izvještaj zaključuje riječima da su navečer ulice puste, stanovništvo uz radio čeka vijesti o još uvijek neiz-

31 U literaturi se na temelju tajnoga izvješća Statističkoga zavoda Mađarske iz 1957., odnosno sovjetskih izvora, računa da je u Mađarskoj poginulo oko 2600 osoba i ranjeno oko 19 tisuća, a sa sovjetske strane poginulo je 720 vojnika, a ranjeno oko 2000. RAINER, Az 1956-os magyar forradalom, 104-105. U novije vrijeme međutim imamo svjedočenja liječnika da su mnoge žrtve, pa i ranjenike, evidentirali kao da imaju neku drugu bolest da bi ih zaštitili od buduće odmazde vlasti. To se dogodilo i s bakom Gábora Jobbágyija, koja je ranjena granatom, a liječnik je u bolnički list upisao da je umrla od upale pluća. To je dalo motiv istraživaču da pregleda statistike, pa je ustanovio da 1956. i 1957. ima oko 6, odnosno 5 i pol tisuća više umrlih nego 1955. i 1958. godine. Dijelom na temelju te statistike, dijelom na prikupljenim iskazima medicinskoga osoblja i drugih svjedoka, Jobbágyi je došao do zaključka da je bilo mnogo više civilnih žrtava (oko 8 do 10 tisuća, ali i gubici ustanika i sovjetskih vojnika bili su veći). Trebamo računati is drastičnim povećanjem smrtnosti ranjenika jer su uvjeti u budimpeštanskim bolnicama, posebno tijekom studenoga 1956., podsjećali na uvjete u Vukovaru 1991. godine. Inače, mađarska emigracija uvijek je govorila o najmanje 10 tisuća žrtava. JOBBÁGYI, 1956 és a megtorlás fekete könyve. Mnogi povjesničari u Mađarskoj ne prihvaćaju Jobbágyijeve procjene, ali još nitko nije dao pravi odgovor na spomenuto pitanje povećanja broja umrlih u tim godinama.

${ }^{32}$ Mađarska socijalistička radnička partija osnovana je početkom studenoga 1956. umjesto Mađarske radničke partije. 
vjesnoj sutrašnjici. I u broju od 3. listopada Vjesnik (i Narodni list) izvještava o raspravi Vijeća sigurnosti UN-a o Mađarskoj, u kojoj je predstavnik Francuske osudio ulazak novih sovjetskih postrojbi u Mađarsku.

Narodni list u broju od 4. studenog još piše o preoblikovanju Nagyeve vlade, da bi potom 5. studenog, kao i Vjesnik, izvijestio o sovjetskom upletanju i osnutku Kádárove vlade, čiji je glavni cilj „obrana razvoja socijalističke države”. Titova Jugoslavija priznala je Kádárovu vladu i počevši od toga i hrvatski su listovi u svojim izvještajima o Mađarskoj pisali o stabilizaciji situacije, odnosno socijalističkoga režima. Naravno, jugoslavenski novinari (kao i cijeli svijet, uključujući vodstvo SAD-a) nisu mogli znati da se Hruščov potajno sastao s Titom na Brijunima u noći 2./3. studenog 1956. godine. Na sastanku je Tito dao blagoslov drugoj sovjetskoj intervenciji jer se pobojao da pad komunista u Mađarskoj može ugroziti i njegovu vlast u Jugoslaviji. Navodno je on predložio Hruščovu da se umjesto Ferenca Münnicha János Kádár imenuje za premijera nove mađarske vlade koja bi se formirala u času nove sovjetske intervencije. ${ }^{33}$ Inače, oba mađarska političara tada su se nalazila u Moskvi. Iako se Kádár još 1. studenog primio članstva u Nagyevoj novoj, višestranačkoj vladi, iste je večeri zajedno s Münnichom na poziv sovjetskoga veleposlanika Jurija Andropova otišao u sovjetsko veleposlanstvo, odakle su ih sutradan sovjetskim vojnim avionom prebacili u Moskvu. Ondje su ga sovjetski drugovi 3. studenog nagovorili da prihvati položaj premijera u novoj vladi (rekli su mu da je Tito potvrdio da bi njegovu novu vladu kao i sovjetsku vojnu „pomoć” podržao). Narodni list 6. studenog u svojem komentaru, premda s ponešto distance, ipak pronalazi opravdanje za sovjetsko vojno upletanje i uvjerava Kádára i njegovu vladu u jugoslavensku podršku u borbi za obranu socijalizma. Premda zagrebački list 7. studenog još objavljuje poziv francuskih pisaca u kojem oni istodobno osuđuju britansko-francusko-izraelsko upletanje u pitanje Sueza i sovjetsku intervenciju u Mađarskoj, jugoslavenski veleposlanik pri UN-u Jože

33 Svijet je prvi put mogao o tome dobiti informacije kada su na Zapadu objavljeni Hruščovljevi memoari. KHRUSHCHEV, Khrushchev Remembers. No uistinu vjerodostojan dokaz o tom tajnom sastanku svijet je dobio kada je bivši jugoslavenski veleposlanik u Moskvi Veljko Mićunović objavio knjigu o svojoj moskovskoj diplomatskoj djelatnosti. MIĆUNOVIĆ, Moskovske godine 1956/1958. [na engleskom jeziku: Veljko Mićunović, Moscow Diary, New York, 1980]. Jugoslavenska vlada zapravo je svoje stajalište o mađarskoj krizi objavila u Bijeloj knjizi o mađarskim događajima početkom 1959. i u njoj su navedeni stavovi s brijunskoga sastanka, ali bez spominjanja samoga susreta. Međutim Mićunovićeva knjiga, koja je tiskana u Zagrebu još za Titova života, ne sadržava neke rečenice iz autorova rukopisa: nakon što je Tito poslije malo nećkanja i okolišanja o pitanju strane intervencije u drugoj zemlji ipak jasno izrekao da protiv kontrarevolucije u Mađarskoj ona može biti opravdana i da treba formirati novu (komunističku) vladu, Hruščov je ushićeno digao ruke uvis i uskliknuo „To, to!” Na temelju toga Mićunović je zaključio da se vidjelo da su Rusi upravo zbog toga došli na Brijune, da čuju takvo Titovo stajalište. Ispuštena je i rečenica: „Stav jugoslovenske delegacije posle toga uglavnom je usmeren na tretiranje sovjetske intervencije kao manjeg zla i na nastojanje da se sa njom nanese što manje štete unutarnjem progresivnom socijalističkom razvitku u Mađarskoj kao i interesima međunarodnog socijalizma." Ovdje bih zahvalio profesoru Ivi Bancu, koji mi je ustupio snimku Mićunovićevih izvornih zabilješki o brijunskom sastanku. U prigodi 50. obljetnice mađarske revolucije profesor Banac tu je činjenicu spomenuo u članku „Mađarska 1956.: Kako je Tito prodao Nagya Hruščovu”, objavljenom u Jutarnjem listu 2. studenog 2006. 
Brilej (njegov govor prenosi Narodni list 10. studenog) na skupštini UN-a suprotno francuskom pozivu daje školski primjer primjene dvostrukoga mjerila (osudio je bliskoistočnu agresiju, no okolišao je u vezi sa sovjetskim upletanjem). Na kraju je 11. studenog sam jugoslavenski diktator Josip Broz Tito u govoru u Puli pronašao opravdanje za sovjetsku intervenciju (govorio je o jačanju reakcionarnih, kontrarevolucijskih elemenata koji su doveli u opasnost socijalistički režim), premda se općenito ogradio od takvih upletanja (ovdje ne mogu podrobnije govoriti o reakcijama jugoslavenskoga tiska na jugoslavensko-sovjetske, odnosno jugoslavensko-mađarske napetosti u pitanju najprije Nagyeve „otmice” ili „izručenja” u studenom 1956., odnosno njegova pogubljenja u lipnju 1958., koje bi mogle biti temom zasebnoga članka). ${ }^{34} \mathrm{Ti}$ tov govor u Puli vrlo je važan i u pogledu našega razumijevanja pisanja jugoslavenskoga tiska o cijeloj mađarskoj revoluciji. Zapravo, ako analiziramo sve članke (i izvješća dopisnika iz Budimpešte i uredničke komentare), i to ne samo Zelmanovićeve dopise i vodeće hrvatske listove (Vjesnik i Narodni list) nego i najvažnije beogradske listove, odnosno medijske organe na razini federacije (Politika, Borba, omladinski list Mladost), uočavamo da su se novinari cijelo vrijeme držali načela koja je Tito sažeo u pulskom govoru. ${ }^{35}$ Ivan Ivanji u svojem (zapravo memoarskom) djelu o mađarskoj revoluciji tvrdi da nije bilo cenzure, nitko im odozgo nije naređivao što smiju i ne smiju napisati. Ivanji ima pravo. Samo je zaboravio dodati da su suradnici, dopisnici vodećih jugoslavenskih listova bili birani, pouzdani kadrovi koji su itekako bili svjesni što trebaju pisati, bili su vrlo dobro informirani o „najnovijem partijskom kursu” i rijetko im se omakla neka „greška u koracima”. Koliko je tisak bio pod kontrolom vlasti u cijeloj Jugoslaviji najbolje dokazuje to da jugoslavenski listovi sve do Nagyeva odlaska iz jugoslavenskoga veleposlanstva u Budimpešti uopće ne pišu o tome da je premijer revolucionarne Mađarske ondje zatražio azil.

34 Još se nije našao dokument koji bi i s jugoslavenske strane potvrdio da je jugoslavenski partijski i državni vrh znao kakva će biti sudbina Nagya i njegovih drugova kada su napustili zgradu veleposlanstva Jugoslavije 22. studenog 1956. godine. Iz Mićunovićeva dnevnika (MIĆUNOVIĆ, Moskovske godine 1956/1958., 163) može se razabrati da se jugoslavenska strana na Brijunima obvezala da će naći nekakvo rješenje za Nagya; vjerojatno su u okviru toga „rješenja” dali premijeru Nagyu i grupi oko njega utočište 4. studenog. Na taj način uspješno su ga izolirali (to je navodno Dobrivoje Vidić priznao Kádáru; vidi: Top Secret, sv. I, dok. br. 127). Međutim, Titu je bio potreban samo Imre Nagy komunist, pristaša reformi, ali ne i Imre Nagy koji prihvaća liberalnu demokraciju i ne želi dati ostavku na položaj premijera i time otežava rad Kádárove vlade, one vlade koju je Jugoslavija odmah priznala i podržala. Dakle, Jugoslaveni su se svakako htjeli osloboditi Nagya, ali istodobno i sačuvati obraz pred svijetom, pa su - kako je János Kádár rekao na tajnoj sjednici Privremenoga centralnoga komiteta Mađarske socijalističke radničke partije - iznudili od mađarskoga vođe jamstveno pismo da se Nagy i njegovi mogu vratiti svojim kućama i da im se neće suditi. Kádár je više puta ciljao na to da je u razgovorima rekao jugoslavenskoj strani što će biti s njima u stvarnosti. Top Secret, sv. I, dok. br. 127, sv. II, dok. br. 1 .

35 Titov govor u cijelosti donosi Vjesnik 16. studenog 1956. Druga je stvar da se Tito - iako je želio balansirati između Zapada i Moskve - tim govorom uspio zamjeriti i jednoj i drugoj strani. $\mathrm{Na}$ Zapadu su ga osudili jer je ipak priznao da je dao blagoslov drugoj sovjetskoj intervenciji (prvu intervenciju, odnosno potez Gerőa, koji je umjesto da vlastitim snagama sigurnosti pokuša uvesti red pozvao u pomoć sovjetsku vojsku i time samo dolio ulje na vatru, Tito je oštro osudio). Sovjetski partijski vrh naljutio se pak jer je Tito spomenuo ostatke staljinističkoga razmišljanja u dijelu sovjetske Partije i unatoč odobrenju druge sovjetske vojne akcije koristio izraz intervencija. 
Tu novinarsku samodiscipliniranost dokazuje i ponašanje Đorđa Zelmanovića: kada je u vrijeme Nagyeva pogubljenja 1958. bio dopisnik Vjesnika u Bonnu, Paris Match (saznavši da je za Nagyeva boravka u zgradi jugoslavenskoga veleposlanstva u Budimpešti i Zelmanović boravio ondje) ponudio mu je za jugoslavenske prilike basnoslovni honorar za intervju, a hrvatski novinar odbio je ponudu s nekim izmišljenim razlogom, a zapravo zato što nije smio govoriti o tome. ${ }^{36}$ Inače, jugoslavenski su novinari osim slanja izvješća svojim listovima radili i na izgradnji veza sa sudionicima mađarskih događaja (ali samo s onima ljevičarske orijentacije) i uspostavili kontakte s radničkim savjetima. Te kontakte održavali su i nakon druge sovjetske intervencije, sve dok Kádárova vlada sredinom prosinca nije zabranila rad centralnih organizacija radničkih savjeta (u samim tvornicama još su neko vrijeme djelovali, ali su stavljeni pod kontrolu vlasti). O tome da su jugoslavenski novinari bili nešto više od običnih dopisnika svjedoči i Ivan Ivanji u svojoj knjizi Mađarska revolucija 1956., gdje u prvom poglavlju, „Veče kod Janosa Kadara”, opisuje kako su beogradski novinari predvođeni Đukom Juliusom 28. listopada razgovarali s novim prvim sekretarom Mađarske radničke partije, koji im je u povjerenju rekao: „Recite drugovima u Jugoslaviji da je stvar socijalizma u Mađarskoj propala i ovako i onako.” Prema Ivanjijevu pisanju, Julius i on iste noći umjesto spavanja sjeli su u automobil i otišli u Jugoslaviju (nisu se usudili tu važnu informaciju poslati iz Budimpešte, ni iz zgrade veleposlanstva, a taj detalj iz razgovora nisu rekli ni veleposlaniku Soldatiću), otišli ravno do predsjednika Saveza komunista Vojvodine Geze Tikvickoga i, naravno, tu važnu vijest nisu dali u svoje novine, nego su informaciju dostavili Titovu uredu. ${ }^{37}$

Svakako treba spomenuti da je nakon druge sovjetske intervencije, kada su prestale borbe, brojna delegacija jugoslavenskih novinara ponovo otišla u Budimpeštu i izvještavala o otporu, pa i konačnoj zabrani (centralnih) radničkih savjeta. I Vjesnik 14. prosinca 1956. donosi Zelmanovićev članak (on je tada već bio u Zagrebu) pod naslovom „Početak i kraj radničkih savjeta”. U njemu se hrvatski novinar prisjeća razgovora s članovima budimpeštanskoga centralnoga radničkog savjeta, a konačni zaključak njegova članka jest da ne vjeruje da su ti ljudi, ti pošteni radnici postali kontrarevolucionari ili fašisti (kako ih je u to doba ocijenila Kádárova vlast). Međutim, to Zelmanovićevo stajalište zapravo je u skladu sa stavovima Edvarda Kardelja od 7. prosinca 1956., dakle nije u suprotnosti sa službenom jugoslavenskom politikom prema mađarskoj revoluciji.

36 ZELMANOVIĆ, Mađarska jesen 1956., 148-149.

37 IVANJI, Mađarska revolucija 1956., 7-27. 
Mađarska revolucija na stranicama hrvatskoga emigrantskog tiska

O mađarskoj revoluciji možemo dobiti korjenito drugačiju sliku uzmemo li u ruke listove hrvatskih emigrantskih organizacija na zapadu. Hrvatska revija iz Buenos Airesa posvećuje veliku pozornost mađarskoj revoluciji 1956. (premda kao časopis koji je izlazio kvartalno budimpeštanske događaje očito razlaže s drugačijim pristupom nego dnevni ili tjedni listovi). Međutim, budući da se idući broj pojavio već nakon sovjetskoga upletanja, sloma revolucije i ponovnoga uvođenja partijsko-državne diktature, o mađarskim događajima u kasnu jesen 1956. piše u svjetlu tih saznanja. Inače, zajednička značajka članaka o Mađarskoj u oba broja ovoga uglednoga hrvatskog časopisa jest činjenica da mađarsku borbu za slobodu promatraju uzimajući u obzir i aspekt puta Hrvatske prema neovisnosti. Hrvatska revija u broju koji je izišao nakon sloma revolucije, u prosincu 1956., mađarske se revolucije prisjeća vodećim člankom na dvije stranice napisanim na španjolskom jeziku, zbog važnosti toga pitanja uzimajući u obzir argentinsko čitateljstvo. Naslov članka je „Epopeya Húngara. Homenaje a una nación heroica y mártir" (Mađarska junačka epopeja. Hommage junačkom i mučeničkom narodu). Autor članka naglašava da Hrvati ne pozdravljaju čudesnu borbu Mađara samo zbog toga što su više od 800 godina živjeli zajedno poglavito u bratstvu i miru nego i zato što je njihova tragedija $\mathrm{i}$ hrvatska tragedija, a njihova je borba za slobodu borba i Hrvata.

Hrvatska revija u svojem jubilarnom godišnjaku 1975. objavljuje i dva članka koja se bave (i) temom mađarske revolucije i u nastavku bih citirao: „U načelu, dosta su jasno povučene granice između interesnih zona Rusije i Amerike u Europi. U tom okviru interesnih zona moramo tumačiti tragični svršetak Madžarske revolucije. Madžari su slušali Radio Free Europe, nadali su se američkoj intervenciji, i čak intervenciji Ujedinjenih Naroda, ali nisu računali s krvavim političkim stvarnostima: Madžarska je bila sastavni dio sovjetskog političkog bloka, s članstvom u Varšavskom paktu, i rušenje jednog dijela tog bloka značilo je rušenje dijela sovjetske moći. A to Rusija nije mogla dozvoliti, čak i uz riziko ulaska u novi svjetski rat.” Autor članka potpuno točno vidi razvoj događaja; znamo da je SAD 1956. poštovao postojeću blokovsku podjelu i interesne zone i praktički jasno poručio Sovjetima da se ne trebaju bojati da će Amerika poduzeti bilo kakve vojne mjere zbog Poljske i Mađarske. ${ }^{38}$

\footnotetext{
38 Već je 28. listopada veleposlanik SAD-a pri UN-u Henry Cabot Lodge skrenuo pozornost članicama Vijeća sigurnosti na to da je američki ministar vanjskih poslova John Foster Dulles u govoru 27. listopada u Dallasu izjavio: „Ne smatramo ove države - Poljsku i Mađarsku - našim potencijalnim vojnim saveznicima." Dana 29. listopada veleposlanik SAD-a u Moskvi Charles Bohlen na temelju depeše koju je dobio od svojega ministra javio je gospodarima Kremlja da je predsjednik Eisenhower potvrdio Dullesovo stajalište. To potvrđuje i sam bivši američki veleposlanik u svojim memoarima. BOHLEN, Witness to History. Eisenhower je spomenutu rečenicu ponovio i u radijskom i televizijskom govoru 31. listopada. Taj američki potez zasigurno je utjecao na odluku sovjetskoga vrha o drugoj vojnoj intervenciji 31. listopada jer su Sovjeti doznali da sa strane SAD-a ne trebaju računati ni na kakve ozbiljne mjere koje bi ometale njihove snage u gušenju mađarskoga ustanka. O američkoj politici prema Mađarskoj i Sovjetskom Savezu u tom razdoblju vidi: BORHI, Magyarország a hidegháborúban i BÉKÉS, Az 1956-os magyar forradalom a világpolitikában.
} 
U Hrvatskoj reviji pojavio se i teorijski tekst Rudolfa Hrašćanca, koji razlaže pojam političke razumnosti i kao primjere za opravdanje svojih gledišta navodi mađarsku revoluciju (premda se časopis bavio politikom, ipak je bio prije kulturnoga, znanstvenoga i književnoga karaktera). Prema Hrašćancu, „Madžarska revolucija 1956. [piše ju velikim slovom, op. D. Š.] opravdani je ustanak protiv sovjetske tiranije. Madžari su tom revolucijom dokazali veliku nacionalnu svijest, duboki smisao i razumijevanje što znači sloboda naroda za narodni život da uistinu bude čovjeka dostojan. Pred sovjetskim tankovima bili su, na povijesnu sramotu zapadnih europskih naroda, napose SAD, prepušteni samima sebi. [...] Uzrečica 'mi ne eksportiramo revolucije' u madžarskom slučaju nije imala povijesnu podlogu, jer su Madžari revoluciju sami započeli."

Hrvatski autor piše da je u vrijeme mađarske revolucije narod prekinuo s komunizmom, mladež odgojena u komunističkom duhu zahtijevala je da se na radiju pročita izjava revolucije i slobode, proleteri su inicirali rušenje Staljinova spomenika i novinari partijskoga lista prosvjedovali su protiv svojih dotadašnjih vođa, a pokajnički su priznali da su pisali laži tjerajući glave u jaram tiranije. „Čulo se od nekih analitičara Madžarske revolucije, da je ona predstavljala jedan nerazboriti pothvat, jer nije bilo dostatno sigurnosti da će uspjeti." Međutim, prema hrvatskom autoru, „moralna vrijednost pravedne revolucije uvijek nadilazi veću ili manju vjerojatnost njezina uspjeha. [...] Nitko nije dužan za cijenu fizičkoga života podnositi zatiranje svojih neotuđivih prava".

Časopis Hrvatska država iz Münchena izlazio je češće (mjesečno), povrh toga jedan je broj objavljen dva dana neposredno nakon izbijanja mađarske revolucije i njegov je urednik Branimir Jelić, prepoznavši važnost pitanja, vijest o mađarskim događajima odmah smjestio na prvu stranicu, pod naslovom „Revolucija u Madžarskoj putokaz k slobodi”: „U sadašnjem času svjetska javnost još ne može prosuditi sve faktore, koji su doveli do veličanstvenih i tragičnih događaja u Madžarskoj. Ne znamo, takodjer, što će iz tih događaja nastati. Ali znamo, da su ljudi ustali u borbi protiv sile i da ulog krvi u povijesti nikada nije ostao bez posljedica. Spontanim eksplozijama napaćene narodne duše izlišno je pristupati racionalnim razmišljanjem o pogodnosti trenutka ustanka, o oportunosti načina i t. d. Zato nam ostaje, kao ljudima, da se poklonimo žrtvama; kao pripadnicima Hrvatskog Naroda, koji bije isti udes, da im se divimo, a kao političkim borcima, da uvijek imamo na umu, da ovi događaji leže na liniji Berlin, Poznanj, Pešta...," a kratki članak uokviren na naslovnici Jelić zaključuje parolom: „Sloboda!”

Hrvatska država i u sljedećim se brojevima redovito vraćala na događaje mađarske revolucije. Branimir Jelić u idućem broju u svojem članku, nastalom u svjetlu konačnoga ishoda u Mađarskoj, pod naslovom „Komunizmu je pukla kičma - Razmatranje povodom poljskog i madjarskog ustanka” pravilno prepoznaje svjetsku povijesnu važnost mađarske revolucije i povode sovjetskoga upletanja: „Poznanjski ustanak bio je povodom demonstracije u Budimpešti, a njeno brutalno ugušenje - uzrokom ustanka u Pešti, dolaska na vlast Imre Nagya, koji je na koncu osjetio u sebi glas svog naroda i radije pošao s naro- 
dom, nego sa strankom, za koju je uvidio da je ispovijedala program, iza koga se krila ne samo brutalna tiranija, nego još jača socijalna nepravda od one, koja ga je nekoć dovela da se priključi komunizmu. - Junaštvo Madjarskog naroda elektriziralo je sve narode pod komunističkim režimom i tiranijom, i u tren oka sovjetsko je carstvo bilo pred rasulom." Prema Jeliću, pobjeda mađarske revolucije pokrenula bi eroziju cijeloga svjetskoga komunističkog režima jer se pokazalo da čak ni $2 \%$ naroda ne stoji uz komuniste i sovjetsko je partijsko vodstvo osjećalo da je upletanje za njega egzistencijalno pitanje i radije je uklonilo antistaljinističke parole XX. kongresa SKP-a i s najstaljinističkijom brutalnošću ugušilo borbu mađarskoga naroda. Prema hrvatskom autoru, veo je pao i s Tita jer je prepoznao da bi pobjeda Mađara donijela pad komunizma i zbog toga je, zaboravivši parole o pravu malih zemalja na neovisnost, uvjerio Sovjete u svoju podršku za sloma mađarskoga ustanka. Jugoslavija je bila u osjetljivom položaju, ovisila je o gospodarskoj pomoći i suradnji sa Zapadom, ali je Tito ipak bio komunist i nije htio ponovo doživjeti totalni raskid sa Sovjetskim Savezom. Idućih godina sovjetsko-jugoslavenski, pa i mađarsko-jugoslavenski odnosi doživljavali su uspone i padove (potonji ponajviše zbog Nagyeva slučaja), ali na kraju je presudilo da nijedna strana nije željela konačan raskid, pa je sljedećih desetljeća Moskva shvatila da joj je važnije što Jugoslavija i unutar Pokreta nesvrstanih pazi da ne ugrozi vitalne sovjetske interese nego izravna kontrola nad Beogradom. U mađarsko-jugoslavenskim odnosima prešli su pak preko Nagyeva slučaja, a Tito i Kádár izgradili su čak srdačne osobne odnose i održavali prihvatljivu razinu bilateralnih veza.

Hrvatska država u istom broju objavljuje članak Ante Cilige (poznatoga „disidenta” komunističkoga pokreta) pod naslovom „Tito osjeća, da je on na redu”. Članak je napisan nakon govora jugoslavenskoga diktatora 11. studenog 1956. godine. Ciliga taj govor duboko osuđuje i naziva ga Titovom duhovnom smrću jer, po njegovu mišljenju, Tito - koji je bio simbol nacionalne borbe za neovisnost, borbe protiv staljinističkoga Sovjetskog Saveza - sad podržava istu sovjetsku velesilu u razaranju neovisnosti jedne male zemlje. Prema Ciligi, Tito je time što se okrenuo protiv Nagya, mađarskoga naroda i mađarske revolucije zapravo kapitulirao pred staljinizmom. Time što je pružio podršku Moskvi i njezinu kvislingu Kádáru Tito je poništio vlastitu duhovnu veličinu i zaslužio da on bude sljedeći komunistički diktator kojega će pomesti bijes naroda (Ciligino se proročanstvo, kao što znamo, nije ostvarilo). U istom broju u članku pod naslovom „Mađarska revolucija i mi” Drago Rakoš mađarski ustanak predstavlja Hrvatima kao uzor koji bi trebali slijediti. List se sličnom argumentacijom vraća na mađarske događaje i u sljedećem broju u tekstu „Hrvatska mladost i mađarska revolucija”. Autor Ivica Pavlinović najveću važnost mađarske revolucije vidi u tome da se jedinstvo komunističkoga bloka, koje se činilo monolitno, slomilo i pokazalo se da narodne mase ne stoje iza režima, a mađarska mladež odgojena u komunističkom duhu ušla je u borbu sa svojim nekadašnjim instruktorima. Hrvatska država opetovano se vraćala na temu mađarske 1956. godine. I nekoliko brojeva poslije na naslovnici je 
dobio mjesto članak „Titova Jugoslavija i madžarska revolucija”. Autor pod inicijalima D. K. opetovano ističe značenje mađarske revolucije u životu zemalja iza „željezne zavjese” i oštro osuđuje SAD zbog toga što podržava titoističku Jugoslaviju koja - kao što dokazuje i Titov govor u Puli - odbacuje i temeljne vrijednosti Zapada.

U našem razdoblju list Hrvatske seljačke stranke izlazi tjedno: to je Hrvatski glas iz kanadskoga Winnipega, časopis koji u brojevima od 29. listopada i 5. studenog 1956. o mađarskom ustanku piše s velikim suosjećanjem i pun nade. U potonjem broju Bogdan Radica u članku „Titovo pravo lice” (koji je - budući da je riječ o tjedniku - gotovo sigurno napisao još prije sovjetske intervencije 4. studenog) tvrdi: premda se Tito nada da će Nagy odvesti Mađare do nekakva titoističkoga nacionalnoga komunizma, narod jednoznačno želi pravu demokraciju i ne ukida samo sovjetsku okupaciju i staljinizam, nego sve forme komunističkoga režima. Autor prognozira da će Tito izdati Mađare i sklopiti pakt sa Sovjetima (kao što znamo, tako se i dogodilo na Brijunima, op. D. Ś.). Hrvatski glas u broju od 12. studenog oplakuje mađarsku revoluciju i izražava solidarnost s mađarskim narodom.

Tjednik Danica iz Chicaga bio je list katoličke orijentacije i jedna od najstarijih emigrantskih tiskovina. I tijekom listopada i studenog i prosinca 1956., ali i 1957. godine bavio se mađarskom revolucijom na istaknutom mjestu, autori lista bili su dobro informirani i već su prethodno pratili mađarske događaje. Tako npr. u broju od 24. listopada 1956. list izvještava o zahtjevima mađarskih pisaca za slobodu književnoga stvaralaštva. O revoluciji tjednik donosi prve članke u broju od 31. listopada. Na naslovnoj stranici donosi članak „Ustanak u Mađarskoj”, ali se i na drugoj i trećoj stranici bavi mađarskim događajima i vrlo pesimistički (realistički) piše da borba „može svršiti samo porazom, ne dođe li pomoć izvana”. Danica u broju od 7. studenog još izvještava o oslobođenju kardinala Józsefa Mindszentya, a u broju od 14. studenog već govori o drugoj sovjetskoj agresiji i duboko osuđuje Tita zbog podrške sovjetskom agresoru. Po pisanju lista, Tito je tako postupio jer se uplašio da u slučaju pobjede mađarske revolucije on dolazi na red i da će narodi Jugoslavije slijediti mađarski primjer („Jedino je Tito odobrio sovjetsku agresiju u Mađarskoj i to iz straha da bi potlačeni narodi u 'Jugoslaviji!' slijedili mađarski primjer, ako bi on bio uspješan."). Naime, u tom članku list je izvijestio svoje čitatelje da su se čak i američki komunisti ogradili od sovjetske intervencije. Autor međutim nema pravo da je Tito bio jedini, jer su osim istočnoeuropskih komunističkih partija npr. i francuski komunisti odobrili sovjetski potez. U istom broju list englesko-francusko-izraelsku agresiju protiv Egipta naziva udarcem nožem u leđa mađarskom pokretu za slobodu i pokretu svih istočnoeuropskih naroda. Danica u prosincu još s nadom izvještava o otporu radničkih savjeta u članku „Madžarska pred novim ustankom” (12. prosinca), odnosno u članku „Plodovi madžarskog ustanka” (19. prosinca) i poziva se na Milovana Đilasa, koji je napisao da u mađarskoj revoluciji vidi početak pada komunizma. Tjednik dodaje i da je Tito zbog toga članka strpao u zatvor svojega bivšeg suborca: 
„Pa ipak rana koju mu [komunizmu, op. D. Š.] je madžarski ustanak zadao, za njega je smrtonosna. Đilas vidi svršetak svakog komunizma. Čak i Tito koji hapsi Đilasa radi te javno iznesene tvrdnje, priznaje da je komunizam kao cjelina dobio jak udarac, izbjegavajući da išta jasnije rekne, koliko je taj udarac bio jak."

Zajedničar, list Hrvatske bratske zajednice, donosi u 50. broju od 12. prosinca članak „Madžarska revolucija”, koji sa simpatijama piše o mađarskom ustanku i tvrdi: „Događaji u Poljskoj i Madžarskoj vrlo su značajni i moguće se time piše nova epoha svjetske povijesti." Međutim, u božićnom broju od 17. prosinca u članku „Mađarska i Jugoslavija” autor ipak ponavlja mnoge negativne stereotipe o povijesnim vezama Mađara i Hrvata, odnosno Južnih Slavena. Danica u broju od 2. siječnja 1957. osuđuje Zajedničara zbog toga napisa i tvrdi da je u tom tragičnom povijesnom trenutku čak nedostojno govoriti o nekim starim grijesima Mađara. Zanimljivo je što Danica spočitava Zajedničaru da je on jedini emigrantski list koji od Titova domaćega tiska zna dobiti i pohvale.

Hrvatska, časopis koji je izlazio u Buenos Airesu svaka dva-tri tjedna, i Republika Hrvatska (bliski emigrantima koji su bili Pavelićevi pristaše) također su dale istaknuto mjesto mađarskoj revoluciji. Hrvatska u broju od 7. studenog o mađarskom ustanku piše sa simpatijom, no prema Nagyu i Władysławu Gomułki iz Poljske odnosi se s potpunim nepovjerenjem. Sljedeći broj Hrvatske od 22. studenog, nakon pada ustanka, upoznaje čitatelje s događajima mađarske revolucije kroz pripovijest jednoga svjedoka i mađarskoga borca za slobodu. Republika Hrvatska i godinu dana poslije, u studenome 1957., prisjeća se mađarske revolucije. U članku „Zapad bez odgovornosti” Mladen Petrić skreće pozornost čitatelja na činjenicu: Zapad je preko radija Slobodna Europa Mađare i potlačene narode pod komunističkom vladavinom bodrio na otpor, a kada su ustali, kao Mađari u listopadu '56. godine, ostavio ih je na cjedilu.

Kao zanimljivost napominjem da i Hrvatska (u broju od 22. studenog 1956.) i Hrvatska država (u broju 18-19 iz veljače 1957.) donose vijest o odjecima mađarske revolucije u krugu jugoslavenskih Hrvata. Prema oba lista, mnogi su simpatizirali s pitanjem Mađara, štoviše UDBA je navodno privela zagrebačke studente, odnosno ličke i hercegovačke seljake Hrvate zbog toga što su otvoreno podržavali borbu Mađara protiv komunista. Hrvatska 22. studenog 1956., pozivajući se na informativnu agenciju hrvatskih emigranata Croatia Press, piše da je hrvatska mladež čak u više navrata izrazila solidarnost s mađarskim domoljubima. List piše da je Titova policija u Zagrebu uhitila grupu studenata. Studente su u zatvoru nemilosrdno pretukli. ${ }^{39}$

Hrvatska država iz Münchena piše o izrazima simpatije hrvatskoga provincijskog stanovništva, odnosno o utjecaju mađarske revolucije među njima (u članku „Odjeci dogadjaja u Mađarskoj”) u veljači 1957. godine. Prema listu,

39 Bilo bi vrlo važno da što hitnije netko od hrvatskih povjesničara metodom usmene povijesti intervjuira svjedoke toga vremena o odjeku mađarske revolucije u Hrvatskoj i hrvatskim krajevima Bosne i Hercegovine dok ne bude kasno (već su i tadašnji 18-godišnjaci danas u dobi od preko 80 godina). 
u Klani u blizini Rijeke 37-godišnji vozač Stanko Raspor izjavio je: „Jugoslavija će biti druga Madjarska! Želio bih, da vidim onoga, koji bi kazao, da mu je dobro u Jugoslaviji." Idućega je dana jugoslavenska državna služba sigurnosti UDBA privela njega i tri osobe iz njegove publike. Potonje su ubrzo pustili na slobodu, a Raspor se, prema riječima tijela vlasti, objesio u zatvoru. Njegovo mrtvo tijelo vratili su rodbini, no nisu dopustili da ga liječnik pregleda, ali su na njemu navodno bili vidljivi tragovi strahovitoga mučenja. U Uzarićima pored Širokoga Brijega u zapadnoj Hercegovini, naseljenoj Hrvatima, kad su nadležni partijski organi željeli organizirati „konferenciju” za stanovništvo da bi objasnili mađarsku situaciju, mještani su se bunili i netko je odbrusio drugovima: „Što imate više držati konferencije? Vama je kucnuo zadnji čas!” Navodno je zbog toga UDBA uhitila 50 ljudi. U tom članku hrvatski list iz Münchena piše da je UDBA u strahu od mađarskih događaja pretresala kuće u okolici Čapljine i navodno nabasala na oružje nedavno uzeto iz skrivenih skladišta.

\section{Zaključak}

Jugoslavenski (hrvatski) tisak donosi zanimljiva izvješća s mjesta događaja i na taj način uspio je detaljnije informirati svoje čitateljstvo o tragičnim zbivanjima u susjedstvu. Upravo zbog toga vrijedi pročitati te članke. Posebno bih istaknuo izvješća Đorđa Zelmanovića, koji vrlo staloženo, u osnovi sa simpatijama, piše o običnim ljudima i događajima u Budimpešti. Međutim, pri ocjeni mađarskih događaja socijalistički tisak nije se, naravno, mogao osloboditi od ideoloških okvira i te povijesne događaje promatrao je u skladu s politikom i ideologijom SKJ koju su odredili Josip Broz Tito i partijski ideolog Edvard Kardelj. Uloga jugoslavenskoga političkog vrha u događajima u Mađarskoj posebno je zanimljiva i svakako će biti predmetom novih istraživanja.

Već i na temelju nekoliko citata koje sam naveo vidi se koliko je hrvatski emigrantski tisak drugačije ocijenio mađarsku revoluciju od titoističkoga hrvatskog novinstva. U hrvatskom emigrantskom tisku o mađarskim događajima pisali su najugledniji, najistaknutiji članovi hrvatske emigracije: Vinko Nikolić, Branimir Jelić, Ante Ciliga, Bogdan Radica i drugi. Neovisno o tome što su se hrvatski emigranti uzaludno nadali skorašnjem padu komunizma, pravilno su prepoznali povijesnu važnost mađarskih događaja.

\section{Objavljeni izvori i tisak}

Danica (Chicago), 1956-1957.

Foreign Relations of the United States, 1955-1957. Government Printing Office. Washington, 1990.

FRANKOVICS, György. Jugoszláv diplomáciai iratok(I.). Magyar-jugoszláv kapcsolatok (1945-1956) [rukopis].

Hrvatska (Buenos Aires), 1956. 
Hrvatska država (München), 1956.

Hrvatska revija (Buenos Aires), 1956, 1976.

Hrvatski glas (Winnipeg), 1956.

Narodni list (Zagreb), 1956.

Republika Hrvatska (Buenos Aires), 1956-1957.

Sovjetskij Sojuz i vengerskij krizis 1956. goda. Dokumenti, ur. Elena D. Orehova, Vyacheslav T. Sereda, Alexander S. Stikalin. Moskva: Rosspen, 1998.

Top Secret. Magyar-jugoszláv kapcsolatok 1956-1959. Sv. I-II, ur. József Kiss, Zoltán Ripp, István Vida. Budapest: MTA Jelenkorkutató Bizottság, 1995.

United Nations report on the Hungarian uprising 1956. Report of the Special Committee on the Problem of Hungary. General Assembly official records: eleventh session, supplement No 18 (A/4592). New York, 1957.

Vjesnik (Zagreb), 1956.

Zajedničar (Pittsburgh), 1956.

\section{Literatura}

BANAC, Ivo. Sa Staljinom protiv Tita. Zagreb: Globus, 1990.

BÉKÉS, Csaba. Az 1956-os magyar forradalom a világpolitikában: tanulmányok és válogatott dokumentumok. Budapest: 1956-os Intézet, 1996.

BOHLEN, Charles E. Witness to History, 1929-1969. New York: W. W. Norton, 1973.

BORHI, László. Hungary in the Cold War 1948-1956: Between the United States and the Soviet Union. Budapest; New York: CEU Press, 2004.

BORHI, László. Magyarország a hidegháborúban. Az Egyesült Államok és a Szovjetunió között, 1945-1956. Budapest: Corvina Kiadó, 2005.

CLISSOLD, Stephen, ur. Yugoslavia and the Soviet Union 1939-1973: A Documentary Survey. London: Oxford University Press, 1975.

ĆOSIĆ, Dobrica. Sedam dana u Budimpešti. Beograd: Nolit, 1957.

ĐILAS, Milovan. Tito. Wien; München: Molden, 1980.

FEJTÖ, François. Behind the Rape of Hungary. Foreword by Jean-Paul Sartre. New York: D. McKay, 1957.

GATI, Charles. Failed illusions: Moscow, Washington, Budapest and the 1956 Hungarian revolt. Washington: Woodrow Wilson Center Press, 2006.

GOLDSTEIN, Ivo. Hrvatska 1918-2008. Zagreb: Novi Liber; Europapress holding, 2008.

GOLDSTEIN, Ivo; GOLDSTEIN, Slavko. Tito. Zagreb: Akademska knjiga, 2015.

GRANVILLE, Johanna. The First Domino: International Decision Making during the Hungarian Crisis of 1956. College Station: Texas A\&M University Press, 2004. 
HALÁSZ de BÉKY, Iván L. The Bibliography of the Hungarian Revolution 1956. Toronto: Toronto University Press, 1963.

HORVÁTH, Miklós. 1956 hadikrónikája. Budapest: Akadémiai Kiadó, 2003.

IVANJI, Ivan. Mađarska revolucija 1956. Beograd: Samizdat B92, 2007.

JOBBÁGYI, Gábor. 1956 és a megtorlás fekete könyve. Budapest: Kairosz Kiadó, 2016.

JUHÁSZ, József. „Pasicstól Titóig”. U: Párhuzamos politikus-portrék a XX. századi Kelet-Közép-és Kelet-Európából, ur. Ottó Szabolcs. Budapest: ELTE BTK, 1994, 51-59.

JUHÁSZ, József. Volt egyszer egy Jugoszlávia. Budapest: Aula, 1999.

KAHLER, Frigyes; M. KISS, Sándor. Forradalom és szabadságharc Magyarországon, 1956. Győr: Korona Kiadó, 2002.

KHRUSHCHEV, Nikita. Khrushchev Remembers. London: Andre Deutsch, 1971.

KOPÁCSI, Sándor. In the Name of the Working Class. Toronto: Lester \& Orpen Dennys, 1986.

KOVAČEVIĆ, Katarina. „Mađarske izbeglice u Jugoslaviji 1956-1957. godine”. Tokovi istorije (2003), br. 1-2: 91-124.

LASKY, Melvin J. The Hungarian Revolution: A White Book. London: Secker and Warburg, 1957.

LITVÁN, György, ur. The Hungarian Revolution of 1956: Reform, Revolt and Repression, 1953-1963. Preveli i uredili János M. Bak i Lyman H. Legters. London; New York: Longman, 1996.

LOMAX, William. Hungary 1956. London: Allison and Busby, 1976.

MÉRAY, Tibor. Thirteen Days That Shook the Kremlin. New York: Praeger, 1959.

MIĆUNOVIĆ, Veljko. Moskovske godine 1956/1958. Zagreb: Sveučilišna naklada Liber, 1971.

MURBER, Ibolya. „Az 1956-os magyar események hatása a jugoszláv-magyar kapcsolatok alakulására és a menekültkérdés”. Limes 18 (2006), br. 3: 71-82.

POPIN, Vladimir. 1956 - a belgrádi és vajdasági sajtó tükrében [1956. - u svjetlu beogradske i vojvođanske štampe]. Novi Sad: Forum, 2006.

RADELIĆ, Zdenko. Hrvatska u Jugoslaviji 1945. - 1991. Od zajedništva do razlaza. Zagreb: Školska knjiga; Hrvatski institut za povijest, 2006.

RAINER, János M. Az 1956-os magyar forradalom. Budapest: Osiris, 2016.

RAINER, János M. Nagy Imre. Budapest: Nagy Imre Alapítvány Kiadó, 2016.

RIPP, Zoltán. 1956. Forradalom és szabadságharc Magyarországon. Budapest: Korona Kiadó, 2002. 
RIPP, Zoltán. Belgrád és Moszkva között (A jugoszláv kapcsolat és a Nagy Imre-kérdés). Budapest: Politikatörténeti Alapítvány, 1994.

SOKCSEVITS, Dénes. „Az 1956-os magyar forradalom a horvát sajtó tükrében”. Limes 18 (2006), br. 3: 95-107.

STIKALIN, Aleksandr. Prervannaja revoljucija. Vengerskij krizis 1956. goda i politika Moskvy. Moskva: Novij hronograf, 2003.

SZTIKALIN, Alekszandr. „A magyarok hősiessége elismerésre méltó. Két orosz tudós az 1956. évi magyar forradalomról”. Limes 18 (2006), br. 4: 51-64.

SZAKOLCZAI, Attila. Az 1956-os forradalom és szabadságharc. Budapest: Kossuth Kiadó, 2006.

VÁLI, Ferenc Albert. Rift and Revolt in Hungary: Nationalism versus Communism. Boston: Harvard University Press, 1961.

VARGA, László, ur. 1956. A forradalom kronológiája és bibliográfiája. Budimpešta: Századvég, 1990.

ZELMANOVIĆ, Đorđe. Mađarska jesen 1956. Zaprešić: Fraktura, 2006. 


\section{SUMMARY}

\section{The Hungarian Revolution of 1956 in Light of the Croatian Press}

This work covers the echoes of the Hungarian Revolution of 1956 in the contemporaneous Croatian press. It is focused on articles and reports published in 1956, partly during the summer just before the revolution, and mostly on contemporaneous newspaper articles (October, November, December), also encompassing some articles published during the first months of 1957. Furthermore, this paper presents and analyses the echoes of the events in Hungary in the leading newspapers of the Socialist Republic of Croatia (Vjesnik, Narodni list), giving an equal amount of attention to articles published in the Croatian émigré press (Hrvatska revija, Hrvatska država, Hrvatski glas, etc.). In addition, the complex Yugoslav-Hungarian and Yugoslav-Soviet relations of that time are examined.

Key words: de-Stalinisation; Soviet bloc; Hungarian-Yugoslav relations; revolution and national uprising; 1956 